\title{
Inhibitory Signaling to Ion Channels in Hippocampal Neurons Is Differentially Regulated by Alternative Macromolecular Complexes of RGS7
}

\author{
Olga I. Ostrovskaya, ${ }^{1}{ }^{\circledR C}$ Cesare Orlandi, ${ }^{1}{ }^{\circledR}$ Ana Fajardo-Serrano, ${ }^{2}$ Samuel M. Young, Jr., ${ }^{3}$ Rafael Lujan, ${ }^{2}$ \\ and $\odot$ Kirill A. Martemyanov ${ }^{1}$ \\ ${ }^{1}$ Department of Neuroscience, The Scripps Research Institute, Jupiter, Florida 33458, ${ }^{2}$ Departamento de Ciencias Médicas, Facultad de Medicina, \\ Universidad de Castilla-La Mancha, 02006 Albacete, Spain, and ${ }^{3}$ Departments of Anatomy and Cell Biology and Department of Otolaryngology, Iowa \\ Neuroscience Institute, and Aging Mind Brain Initiative, University of Iowa, Iowa City, Iowa 52242
}

The neuromodulatory effects of GABA on pyramidal neurons are mediated by $\mathrm{GABA}_{\mathrm{B}}$ receptors $\left(\mathrm{GABA}_{\mathrm{B}} \mathrm{Rs}\right)$ that signal via a conserved G-protein-coupled pathway. Two prominent effectors regulated by $\mathrm{GABA}_{\mathrm{B}}$ Rs include G-protein inwardly rectifying $\mathrm{K}^{+}(\mathrm{GIRK})$ and $\mathrm{P} / \mathrm{Q} / \mathrm{N}$ type voltage-gated $\mathrm{Ca}^{2+}\left(\mathrm{Ca}_{\mathrm{V}} 2\right)$ ion channels that control excitability and synaptic output of these neurons, respectively. Regulator of G-protein signaling 7 (RGS7) has been shown to control $\mathrm{GABA}_{\mathrm{B}}$ effects, yet the specificity of its impacts on effector channels and underlying molecular mechanisms is poorly understood. In this study, we show that hippocampal RGS7 forms two distinct complexes with alternative subunit configuration bound to either membrane protein R7BP (RGS7 binding protein) or orphan receptor GPR158. Quantitative biochemical experiments show that both complexes account for targeting nearly the entire pool of RGS7 to the plasma membrane. We analyzed the effect of genetic elimination in mice of both sexes and overexpression of various components of RGS7 complex by patch-clamp electrophysiology in cultured neurons and brain slices. We report that RGS7 prominently regulates GABA $\mathrm{R}$ signaling to $\mathrm{Ca}_{\mathrm{V}} 2$, in addition to its known involvement in modulating GIRK. Strikingly, only complexes containing R7BP, but not GPR158, accelerated the kinetics of both GIRK and $\mathrm{Ca}_{\mathrm{V}} 2$ modulation by $\mathrm{GABA}_{\mathrm{B}} \mathrm{Rs}$. In contrast, GPR158 overexpression exerted the opposite effect and inhibited RGS7-assisted temporal modulation of GIRK and $\mathrm{Ca}_{\mathrm{V}} 2$ by GABA. Collectively, our data reveal mechanisms by which distinctly composed macromolecular complexes modulate the activity of key ion channels that mediate the inhibitory effects of GABA on hippocampal CA1 pyramidal neurons.

Key words: GABAB; GPCR; hippocampus; ion channels; neuromodulation; RGS

\section{Significance Statement}

This study identifies the contributions of distinct macromolecular complexes containing a major G-protein regulator to controlling key ion channel function in hippocampal neurons with implications for understanding molecular mechanisms underlying synaptic plasticity, learning, and memory.

\section{Introduction}

The hippocampus plays a crucial role in learning, memory, and spatial navigation by processing the incoming signals from cortex

\footnotetext{
Received May 30, 2018; revised Sept. 1, 2018; accepted Sept. 26, 2018.

Author contributions: 0.I.0. wrote the first draft of the paper; 0.I.0., C.O., A.F.-S., S.M.Y., R.L., and K.A.M. edited the paper; 0.I.O., R.L., and K.A.M. designed research; 0.I.O., C.O., A.F.-S., and R.L. performed research; S.M.Y. contributed unpublished reagents/analytic tools; 0.I.0., C.O., R.L., and K.A.M. analyzed data; K.A.M. wrote the paper.

This work was supported by the National Institutes of Health (Grants DA021743, DA026405, and MH105482 to K.A.M.), the Spanish Ministry of Education and Science (Grant BFU-2015-63769-R to R.L.), and the European Union (HBP Project Reference 720270 to R.L.). We thank Dr. Said Kourrich for technical advice and discussions and Mrs. Natalia Martemyanova for help with animal breeding and genotyping.

The authors declare no competing financial interests.
}

through the trisynaptic circuit composed of sequentially connected neurons in dentate gyrus, CA3, and CA1 regions (Stepan et al., 2015). Critical to this process is the inhibitory influence of GABA imposed by a variety of interneurons on the CA1 pyramidal neurons that provide main output from hippocampus (Klausberger and Somogyi, 2008; Pelkey et al., 2017). Many of the GABA effects on CA1 pyramidal neurons are mediated by

0.I. Ostrovskaya's present address: Center for Learning and Memory, Institute for Neuroscience, University of Texas at Austin, Austin, TX 78712

Correspondence should be addressed to Kirill A. Martemyanov, Department of Neuroscience, The Scripps Research Institute, 130 Scripps Way \#3C2, Jupiter, FL 33458. E-mail: kirill@scripps.edu.

https://doi.org/10.1523/JNEUROSCI.1378-18.2018

Copyright $\odot 2018$ the authors $\quad 0270-6474 / 18 / 3810002-14 \$ 15.00 / 0$ 
$\mathrm{GABA}_{\mathrm{B}}$ receptors $\left(\mathrm{GABA}_{\mathrm{B}} \mathrm{Rs}\right)$ that belong to G-protein-coupled receptor (GPCR) superfamily and signal via heterotrimeric $\mathrm{G}_{\mathrm{i} / \mathrm{o}}$ proteins (Padgett and Slesinger, 2010).

The $\mathrm{GABA}_{\mathrm{B}} \mathrm{Rs}$ mediate their inhibitory effects by activating several signaling pathways most prominently including direct modulation of ion channels by G-protein $\beta \gamma$ subunits. In the dendrites, $\mathrm{G} \beta \gamma$, liberated from $\mathrm{G} \alpha_{\mathrm{i} / \mathrm{o}}$ by $\mathrm{GABA}_{\mathrm{B}} \mathrm{Rs}$, binds and opens G-protein-gated inwardly rectifying $\mathrm{K}^{+}$(GIRK/Kir3) channels, producing slow IPSCs (sIPSCs) and the ensuing hyperpolarization and decrease in excitability (Lüscher and Slesinger, 2010; Dascal and Kahanovitch, 2015). In the axons, $G \beta \gamma$, released by the $\mathrm{GABA}_{\mathrm{B}} \mathrm{Rs}$, binds and inhibits $\mathrm{Ca}_{\mathrm{V}} 2$ voltage-gated channels ( $\mathrm{N}$ and $\mathrm{P} / \mathrm{Q}$ types), suppressing neurotransmitter release and thereby inhibiting the synaptic output of CA1 neurons (Zamponi and Currie, 2013). The inhibitory signaling by $\mathrm{GABA}_{\mathrm{B}} \mathrm{Rs}$ via GIRK and $\mathrm{Ca}_{\mathrm{V}} 2$ is important for hippocampal synaptic plasticity and memory formation (Davies et al., 1991; Wagner and Alger, 1995; Schuler et al., 2001) and its dysfunctions are thought to contribute to a variety of neuropsychiatric conditions including epilepsy, Down syndrome, and motor and cognitive impairments (Schuler et al., 2001; Alonso et al., 2008; Cramer et al., 2010; Zamponi et al., 2010; Victoria et al., 2016)

A critical role in controlling the strength and timing of $\mathrm{GABA}_{\mathrm{B}} \mathrm{R}$ signaling to GIRK in CA1 neurons belongs to the RGS7/ G $\beta 5$ protein complex (Xie et al., 2010; Zhou et al., 2012; Ostrovskaya et al., 2014). Being a constitutive dimer, RGS7/G $\beta 5$ functions as a GTPase activating protein (GAP) that accelerates G-protein inactivation (Anderson et al., 2009) to limit $\mathrm{G} \beta \gamma$ mediated GIRK activation and facilitate current deactivation upon termination of the $\mathrm{GABA}_{\mathrm{B}} \mathrm{R}$ signaling. Accordingly, elimination of either RGS7 (Ostrovskaya et al., 2014) or G $\beta 5$ (Xie et al., 2010) in mice profoundly slows GIRK channel deactivation kinetics and sensitizes GIRK for the inhibitory effect of GABA. Intriguingly, recent studies revealed that, in the brain, RGS7 forms macromolecular complex with two other auxiliary subunits: RGS7 binding protein (R7BP) (Drenan et al., 2005; Martemyanov et al., 2005) and orphan receptor GPR158 (Orlandi et al., 2012). Biochemical studies show that both proteins stimulate RGS7 activity in catalyzing $\mathrm{G} \alpha_{\mathrm{i} / \mathrm{o}}$ deactivation (Drenan et al., 2006; Masuho et al., 2013; Orlandi et al., 2015). Furthermore, R7BP and GPR158 also promote membrane localization of RGS7/G $\beta 5$ in transfected cells and, in the brain, neurons (Drenan et al., 2005; Song et al., 2006; Anderson et al., 2007a; Orlandi et al., 2012). GPR158 was also documented to influence RGS7 abundance in the brain (Orlandi et al., 2015). Interestingly, interaction of RGS7 with R7BP and GPR158 is mutually exclusive (Orlandi et al., 2012), indicating that RGS7 exists in two distinct alternative configurations at the plasma membrane and raising a provocative possibility of functionally distinct complexes involved in regulation of $\mathrm{GABA}_{\mathrm{B}} \mathrm{R}$ signaling. Indeed, evidence supports R7BP involvement in $\mathrm{GABA}_{\mathrm{B}} \mathrm{R}$ function revealing distinct effects on GIRK currents (Zhou et al., 2012; Ostrovskaya et al., 2014). However, the role of GPR158 in this process is completely unknown, as is the contribution of any components of the RGS7 complex to $\mathrm{Ca}_{\mathrm{v}} 2$ regulation.

In this study, we identify $\mathrm{Ca}_{\mathrm{v}} 2$ as an effector ion channel regulated by RGS7 and use molecular and genetic approaches to investigate the role of alternative configurations of RGS7 complexes in controlling $\mathrm{GABA}_{\mathrm{B}} \mathrm{R}$ signaling to $\mathrm{Ca}_{\mathrm{V}} 2$ compared with its impacts on GIRK. We revealed an unexpected mechanism whereby the ability of RGS7 to regulate GIRK and $\mathrm{Ca}_{\mathrm{V}} 2$ is promoted by R7BP but inhibited by GPR158.

\section{Materials and Methods}

Animals. All studies were performed in accordance with National Institutes of Health $(\mathrm{NIH})$ guidelines and were granted formal approval by the Institutional Animal Care and Use Committee of the Scripps Research Institute. The generation of $G \beta 5^{-1-}$ (Chen et al., 2003),

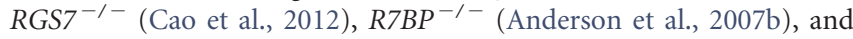
GPR158 ${ }^{-1-}$ (Orlandi et al., 2015) mice were described earlier. All animals used for comparing genotypes were littermates derived from heterozygous breeding pairs. Double knock-out (DKO) mice were generated by breeding R7BP and GPR158 KO mice and then crossing the R7BP KO/GPR158 heterozygous HET parents. Mice were housed in groups on a $12 \mathrm{~h}$ light/dark cycle with food and water available ad libitum. Males and females (2-5 months of age) were used for all experiments.

Antibodies, Western blotting, and recombinant proteins. Lysates were prepared by homogenizing hippocampal tissue from age-matched littermates by sonication in lysis buffer containing $300 \mathrm{~mm} \mathrm{NaCl}, 50 \mathrm{~mm}$ Tris-HCl, $\mathrm{pH} 7.4$, and $1 \%$ Triton X-100 and complete protease inhibitor mixture (Roche Applied Science), incubated on a rocker for $30 \mathrm{~min}$ at $4^{\circ} \mathrm{C}$, and cleared by centrifugation at $14,000 \times g$ for $15 \mathrm{~min}$. The supernatant was saved and the protein concentration was obtained using the $660 \mathrm{~nm}$ Protein Assay (Thermo Fisher Scientific). Samples were diluted in $4 \times$ SDS sample buffer and analyzed by SDS-PAGE. Signals were captured on film, scanned by densitometer, and band intensities were determined using ImageJ software. Rabbit anti-R7BP (TRS) and rabbit G $\beta 5$ (ADTG) were generous gifts from Dr. William Simonds [National Institute of Diabetes and Digestive and Kidney Diseases (NIDDK)-NIH]. Rabbit anti-GIRK1 antibodies were a generous gift from Dr. Kevin Wickman (University of Minnesota, Minneapolis, MN). Rabbit anti-G $\beta 1$ was a generous gift from Dr. Barry Willardson (Brigham Young University, Provo, UT). Rabbit antibodies against the intracellular C terminus of mouse GPR158 (GPR158CT) and N terminus of RGS7 (RGS7NT) were described previously (Orlandi et al., 2015). The following antibodies were used: anti-GAPDH (Millipore), anti-G $\alpha$ o (Cell Signaling Technology), anti-GIRK2 (Alomone Laboratories), anti-GABABR2 (Neuromab), and anti-GFP (Roche Applied Science). Rabbit anti-RGS7 (7RC1) antibodies used for immunogold electron microscopy were a kind gift from Dr. William Simonds (NIDDK/NIH).

Recombinant RGS7 was coexpressed with G $\beta 5$ in $S f 9$ insect cells via baculovirus-mediated delivery and the recombinant complexes were purified by HisTALON Superflow Cartridge (Clontech Laboratories) chromatography using His-tag present at the N termini of RGS7 proteins as described previously (Martemyanov et al., 2005).

Subcellular fractionation. For subcellular fractionation experiments, tissues were homogenized in ice-cold lysis buffer containing $150 \mathrm{mM}$ $\mathrm{NaCl}, 50 \mathrm{mM}$ Tris-HCl, pH 7.4, 1 mM EDTA, $2.5 \mathrm{mM} \mathrm{MgCl}_{2}$, and complete protease inhibitor mixture (Roche Applied Science) by sonication. Lysates were adjusted to the same protein concentration with lysis buffer and equal amounts were subjected to ultracentrifugation $(200,000$ $\times g$ for $30 \mathrm{~min} / 4^{\circ} \mathrm{C}$ ). The supernatant was recovered and designated as cytosolic fraction. The pellet was washed with the lysis buffer and resedimented by centrifugation $\left(200,000 \times g\right.$ for $\left.30 \mathrm{~min} / 4^{\circ} \mathrm{C}\right)$. The pellet was then resuspended in detergent buffer containing $300 \mathrm{~mm} \mathrm{NaCl}, 50$ mм Tris- $\mathrm{HCl}, \mathrm{pH} 7.4,1 \%$ Triton X-100, and complete protease inhibitor mixture, incubated on a rocker for $30 \mathrm{~min} / 4^{\circ} \mathrm{C}$, and cleared by centrifugation at $14,000 \times g$ for $15 \mathrm{~min}$. The supernatant was saved and designated as the membrane fraction.

Recombinant helper-dependent adenovirus for GPR158 overexpression. GPR158 was cloned into the high-level neuronal transgene expression cassette pUNISHER (Montesinos et al., 2011) for rapid and long term in vivo neuronal expression in the CNS as described previously. HdAd was stored at $-80^{\circ} \mathrm{C}$ in storage buffer containing $10 \mathrm{~mm}$ HEPES, $250 \mathrm{~mm}$ sucrose, and $1 \mathrm{~mm} \mathrm{MgCl}_{2}, \mathrm{pH}$ 7.4). Viral particles per milliliter were calculated as follows: viral particles $/ \mathrm{ml}=($ A260 $) \times($ dilution factor $) \times$ $(1.1 \times 1012) \times(36) /($ size of the vector in $\mathrm{kb})$ viral titer: HdAd 23E4 Pun GPR158 syn EGFP $7.11 \times 1012 \mathrm{vp} / \mathrm{ml}$.

In situ hybridization. Expression of Gpr158 and R7bp mRNAs was evaluated with the ViewRNA 2-plex In Situ Hybridization Assay (Affymetrix) using the following probe sets: Gpr158 (NM_001004761; cata- 
log \#VB1-11518), R7bp (NM_029879; catalog \#VB6-16884). A probe against the E. coligene DapB (NC_000913; catalog \#VF1-10272) was used as a specificity control as recommended by the manufacturer. Briefly, mouse brains were embedded in optimal cutting temperature medium, flash frozen in liquid nitrogen, cut in $14 \mu \mathrm{m}$ coronal sections, and rapidly fixed in $4 \%$ paraformaldehyde for $10 \mathrm{~min}$. Sections were then washed and incubated for $2 \mathrm{~h}$ at room temperature in prehybridization mixture containing 50\% deionized formamide, $5 \times$ SSC, $5 \times$ Denhardt's solution, 250 $\mu \mathrm{g} / \mathrm{ml}$ yeast tRNA, and $500 \mu \mathrm{g} / \mathrm{ml}$ sonicated salmon sperm DNA, followed by overnight incubation at $40^{\circ} \mathrm{C}$ with the manufacturer's hybridization solution containing TYPE 1 and TYPE 6 QuantiGene ViewRNA probe sets diluted 1:100. Sections were then processed according to manufacturer's instructions. To identify the soma of the cells, each section was counterstained with NeuroTrace 435/455 Blue Fluorescent Nissl Stain (1:100, Invitrogen) and mounted using Fluoromont-G (Southern Biotech). Images were acquired at The Light Microscopy Facility of the Max Planck Florida Institute using an LSM 880 Zeiss confocal microscope. Image acquisition and processing were performed using ZEN 2011 software (Carl Zeiss) and setting the fluorescence intensity in nonsaturating conditions.

Immunogold electron microscopy. Immunohistochemical reactions were performed using the preembedding immunogold method as described previously (Lujan et al., 1996). Briefly, after blocking with $10 \%$ serum for $1 \mathrm{~h}$ at room temperature, free-floating sections were incubated for $48 \mathrm{~h}$ with anti-RGS7 antibodies $(1-2 \mathrm{mg} / \mathrm{ml})$. Sections were washed and incubated for $3 \mathrm{~h}$ with goat anti-rabbit IgG coupled to $1.4 \mathrm{~nm}$ gold (Nanoprobes) at a 1:100 dilution. Sections were washed, postfixed in 1\% glutaraldehyde, and processed for silver enhancement of the gold particles with an HQ Silver kit (Nanoprobes). The reacted sections were treated with osmium tetroxide $(1 \%$ in $0.1 \mathrm{M} \mathrm{PB})$, block stained with uranyl acetate, dehydrated in graded series of ethanol, and flat embedded on glass slides in Durcupan (Fluka) resin. Regions of interest were cut at $70-90 \mathrm{~nm}$ on an ultramicrotome (Reichert Ultracut E; Leica). Staining was performed on drops of $1 \%$ aqueous uranyl acetate followed by Reynolds's lead citrate. Ultrastructural analyses were performed on a Jeol1010 electron microscope.

To establish the relative the abundance of RGS7 immunoreactivity along the plasma membrane of pyramidal cells, we used $60 \mu \mathrm{m}$ coronal slices processed for preembedding immunogold immunohistochemistry. The procedure was similar to that used previously (Lujan et al., 1996). Briefly, for each of three animals from different postnatal ages and adult, three samples of tissue were obtained for preparation of embedding blocks (totaling nine blocks for each age). To minimize false negatives, electron microscopic serial ultrathin sections were cut close to the surface of each block because immunoreactivity decreased with depth. We estimated the quality of immunolabeling by always selecting areas with optimal gold labeling at approximately the same distance from the cutting surface. Randomly selected areas were then photographed from the selected ultrathin sections and printed with a final magnification of $45,000 \times$. Quantification of immunogold labeling was performed in reference areas totaling $\sim 1800 \mu \mathrm{m}^{2}$ for each age. Immunoparticles identified in each reference area and present in different subcellular compartments (dendritic spines, dendritic shafts, and somata) were counted. We measured the radial distance of each immunoparticle to the plasma membrane, being 0 for those just located in the plasma membrane. The data are expressed as thepercentage of immunoparticles along the radial distance from the plasma membrane expressed in nanometers.

Hippocampal cultures. Primary cultures of hippocampal neurons were prepared using a modified version of a previously published protocol (Xie et al., 2010). Briefly, hippocampi were extracted from neonatal (P1P3) pups and placed into an ice-cold HBSS/FBS solution (SigmaAldrich) containing $4.2 \mathrm{~mm} \mathrm{NaHCO}_{3}, 1 \mathrm{~mm}$ HEPES, and 20\% FBS. The tissue was washed twice with $20 \% \mathrm{FBS}$ and then three times with HBSS. Hippocampi were digested at room temperature for $5 \mathrm{~min}$ with $10 \mathrm{mg} / \mathrm{ml}$ trypsin type XI (Sigma-Aldrich) in a solution containing the following (in mM): $137 \mathrm{NaCl}, 5 \mathrm{KCl}, 7 \mathrm{Na}_{2} \mathrm{HPO}_{4}$, and 25 HEPES, pH 7.2. The tissue was washed yhree times with $20 \%$ FBS and HBSS and then hippocampi were mechanically dissociated in HBSS supplemented with $12 \mathrm{~mm}$ $\mathrm{MgSO}_{4}$ using Pasteur pipettes of decreasing diameter. The neurons were pelleted by centrifugation $\left(600 \times g\right.$ for $10 \mathrm{~min}$ at $\left.4^{\circ} \mathrm{C}\right)$ and plated onto 8 $\mathrm{mm}$ glass coverslips pretreated with Matrigel (BD Biosciences) in a 48well plate. Neurons were allowed to adhere for $30 \mathrm{~min}$ before adding 0.3 $\mathrm{ml}$ of prewarmed culture medium consisting of Neurobasal A (Life Technologies), 2 mm GlutaMAX-I (Life Technologies), 2\% B-27 supplement, and $5 \%$ FBS. After $4-12 \mathrm{~h}$, the culture medium was completely replaced with the same medium without FBS. Neurons were incubated at $37^{\circ} \mathrm{C} / 5 \% \mathrm{CO}_{2}$ and half of the medium was replaced with fresh medium every $2-4 \mathrm{~d}$ of culture. Neurons were cultured for $10-14 \mathrm{~d}$ before experiments.

Somatodendritic GIRK current recordings. For GIRK currents, coverslips containing neurons at DIV 10-13 were transferred to a chamber containing a low- $\mathrm{K}^{+}$bath solution containing the following (in $\mathrm{mm}$ ): $145 \mathrm{NaCl}, 4 \mathrm{KCl}, 1.8 \mathrm{CaCl}_{2}, 1 \mathrm{MgCl}_{2}, 5.5 \mathrm{D}$-glucose, and 5 HEPES, pH 7.4 with $\mathrm{NaOH}$. Borosilicate patch pipettes $(2.5-5 \mathrm{M} \Omega$ ) were filled with the following (in mM): $130 \mathrm{KCl}, 10 \mathrm{NaCl}, 1 \mathrm{EGTA}, 0.5 \mathrm{MgCl}_{2}, 10 \mathrm{HEPES}, \mathrm{pH}$ 7.25 with $\mathrm{KOH}, 2 \mathrm{Na}_{2} \mathrm{ATP}, 5$ phosphocreatine, $0.3 \mathrm{GTP}$. Baclofen $(R-$ (+)-b-(aminomethyl)-4-chlorobenzenepropanoic acid hydrochloride) was purchased from Sigma-Aldrich. Baclofen-induced currents were measured at room temperature using a high- $\mathrm{K}^{+}$bath solution containing the following (in mM): $120 \mathrm{NaCl}, 25 \mathrm{KCl}, 1.8 \mathrm{CaCl}_{2}, 1 \mathrm{MgCl}_{2}, 5.5$ D-glucose, and 5 HEPES, pH 7.4 with $\mathrm{NaOH}$. For $\mathrm{Ba}^{+2}$ current recordings, the external solution contained the following (in $\mathrm{mm}$ ): $138 \mathrm{NaCl}, 4$ $\mathrm{KCl}, 2.5 \mathrm{BaCl}_{2}, 1 \mathrm{MgCl}_{2}, 10$ D-glucose, and 10 HEPES, pH 7.4 with $\mathrm{NaOH}$. The internal solution contained the following (in mM): $100 \mathrm{CsCl}$, 20 TEA-Cl, 10 EGTA, 10 HEPES, $0.5 \mathrm{CaCl}_{2}, 1 \mathrm{MgCl}_{2}, 3 \mathrm{MgATP}$, and 0.3 $\mathrm{Na}_{3} \mathrm{GTP}, \mathrm{pH} 7.25$ with $\mathrm{KOH}$.

The solution ( \pm baclofen) was applied directly to the soma and proximal dendrites with an SF-77B rapid perfusion system (Warner Instruments). The holding potential was $-80 \mathrm{mV}$. Membrane potentials and whole-cell currents were measured in large neurons $(>75 \mathrm{pF})$ with hardware (Axopatch-700B amplifier, Digidata 1440A) and software (pCLAMP v. 10.3) from Molecular Devices. All currents were low-pass filtered at $2 \mathrm{kHz}$, sampled at 5 (GIRK) or $50\left(\mathrm{Ba}^{+2}\right.$ current) $\mathrm{kHz}$, and stored on computer hard disk for subsequent analysis. For GIRK, activation rates were extracted from a standard exponential fit of the current trace corresponding to the onset of drug effect and the peak evoked current and deactivation rates were extracted from an exponential fit of the trace corresponding to the return of current to baseline following removal of drug (Clampfit version 10.3 software). Current desensitization was defined as percentage change in steady-state current from the maximal baclofen-evoked response amplitude during $10 \mathrm{~s}$ of continuous drug application. Only experiments where access resistances $\left(R_{\mathrm{a}} \mathrm{s}\right)$ were stable and low $(<20 \mathrm{M} \Omega)$ were included in the analysis. In experiments with $\mathrm{Ba}^{2+}$ currents, $R_{\mathrm{a}} \mathrm{s}$ were compensated at $50-90 \%$ rate.

Hippocampal slices. Mice were euthanized under isoflurane anesthesia and brains were rapidly removed and placed in ice-cold artificial CSF (aCSF) supplemented with kynurenic acid $10 \mathrm{~mm}$ containing the following (in mM): $124 \mathrm{NaCl}, 3 \mathrm{KCl}, 24 \mathrm{NaHCO}_{3}, 1.25 \mathrm{NaH}_{2} \mathrm{PO}_{4}, 1 \mathrm{MgSO}_{4}$, and 10 D-glucose equilibrated with $95 \% \mathrm{O}_{2}$ and $5 \% \mathrm{CO}_{2}$. The tissue was cut in $300-\mu \mathrm{m}$-thick sections with a vibrating microtome (Leica VT1200S). The slices were warmed to $35^{\circ} \mathrm{C}$ for $25-45 \mathrm{~min}$ in aCSF supplemented with $2 \mathrm{~mm} \mathrm{CaCl}_{2}$ and equilibrated with $95 \% \mathrm{O}_{2}$ and $5 \% \mathrm{CO}_{2}$. Then slices were maintained in gassed aCSF at room temperature until being transferred to submerged-type recording chambers of volume $\sim 1.5 \mathrm{ml}$. The slices were constantly superfused $(1-2 \mathrm{ml} / \mathrm{min})$ with warmed $\left(30-31^{\circ} \mathrm{C}\right)$ and gassed aCSF. All measurements were performed by an experimenter blinded to genotype.

Patch-clamp recordings in slices. CA1 neurons were visually identified in the hippocampal transverse slices of $300 \mu \mathrm{M}$ thickness using the Scientifica SliceScope system. Glass microelectrodes with an open tip resistance of 2.5-5 $\mathrm{M} \Omega$ were used. The internal solution contained the following (in mM): $120 \mathrm{~K}$-gluconate, $20 \mathrm{KCl}, 10 \mathrm{~K}$-HEPES, $0.2 \mathrm{EGTA}, 2$ $\mathrm{MgCl}_{2}, 0.3 \mathrm{Na}_{3} \mathrm{GTP}$, and $4 \mathrm{Na}_{2} \mathrm{ATP}$, pH 7.3 with $\mathrm{KOH}$. Cells with series resistance $>20 \mathrm{M} \Omega$ or resting membrane potentials $>-55 \mathrm{mV}$ were excluded from analysis. Liquid junction potential was $-14 \mathrm{mV}$. Kynurenic acid $2 \mathrm{~mm}$ was added to aCSF to block glutamatergic transmission.

Data analysis. Statistical analyses were performed using Prism (GraphPad Software). Data are presented throughout as the mean \pm SEM. Stu- 
A
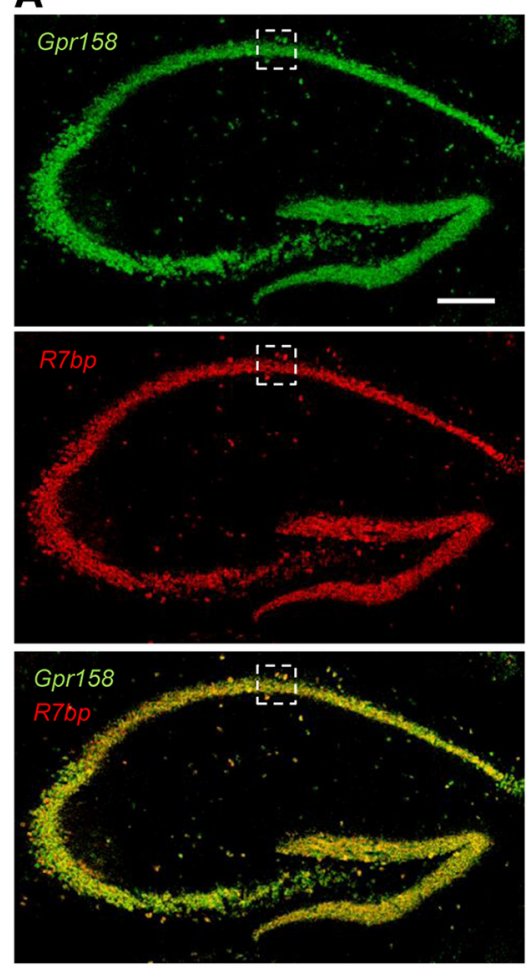

B
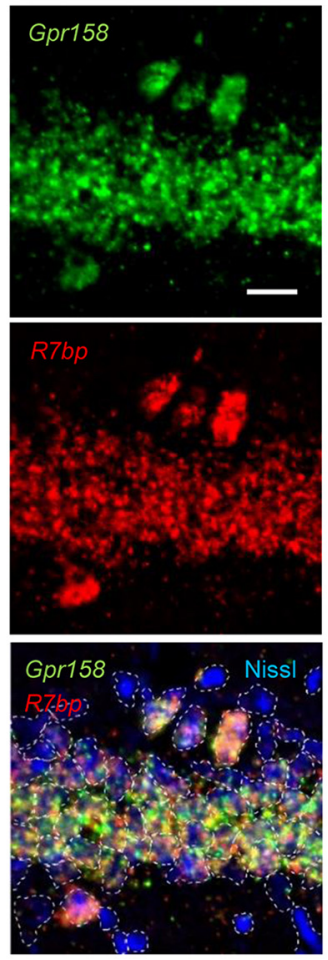

C
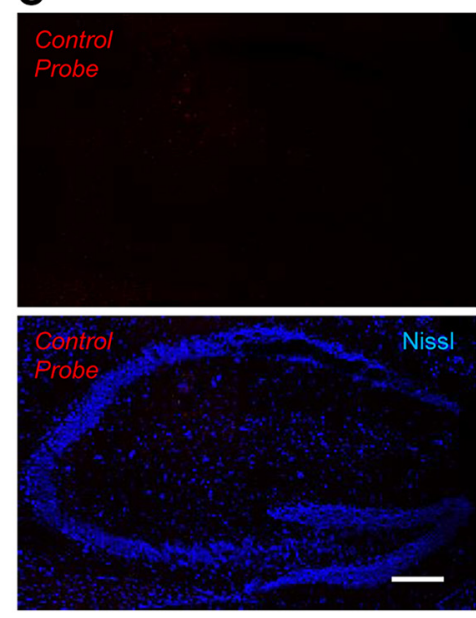

D

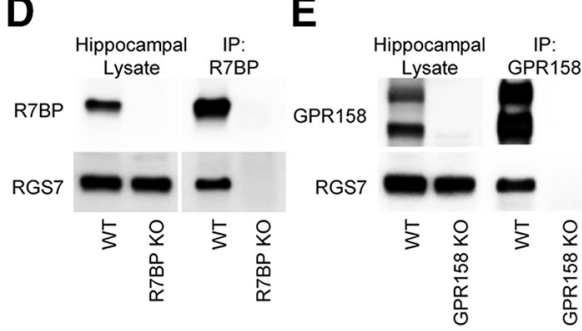

Figure 1. RGS7 in hippocampus exists in alternative configurations bound to either GPR158 or R7BP. $\boldsymbol{A}$, Representative images of a double in situ hybridization using probes against Gpr158 (green) and $R 7 b p$ (red) mRNAs on a coronal section of adult mouse hippocampus. Scale bar, $200 \mu \mathrm{m}$. $\boldsymbol{B}$, Higher magnification of the CA1 area identified by a dashed square in $\boldsymbol{A}$ is reported for each probe. The soma of each cell is identified by Nissl staining (blue). A dashed line was used to assign mRNA expression to individual neurons. In situ hybridizations were conducted on sections from two individual mice. Scale bar, $20 \mu \mathrm{m}$. C, In situ hybridization of a hippocampal section using a control probe against the $E$. coli gene DapB (red). Nissl staining is seen as blue. Scale bar, $200 \mu \mathrm{m}$. $\boldsymbol{D}$, Coimmunoprecipitation of R7BP and RGS7 using specific antibodies against R7BP on hippocampal lysates. R7BP KO lysate was used as a specificity control. $\boldsymbol{E}$, Coimmunoprecipitation of GPR158 and RGS7 from hippocampal lysates using specific antibodies against GPR158. GPR158 K0 lysate was used as a specificity control.

dent's $t$ test, one-way or two-way ANOVA, followed by Bonferroni's or Tukey's post hoc tests were used as appropriate. The minimal level of significance was set at $p<0.05$.

\section{Results}

R7BP and GPR158 each control a significant fraction of RGS7 in the hippocampus

We began by studying the expression of GPR158 and R7BP subunits in the mouse hippocampus. Using sensitive in situ hybridization at a single-cell resolution, we found coexpression of $R 7 b p$ and Gpr158 mRNAs in the majority of hippocampal neurons across all regions including CA1 pyramidal neurons (Fig. 1A,B). A negative control probe did not show any fluorescent labeling, indicating the specificity of the detection (Fig. 1C). To confirm the complex formation between RGS7 and its membrane anchoring subunits R7BP and GPR158 in hippocampal tissue, we performed coimmunoprecipitation experiments. Using this approach, we readily detected complexes of RGS7 with both R7BP (Fig. 1D) and GPR158 (Fig. 1E). The binding specificity was confirmed by using hippocampal lysates obtained from $\mathrm{KO}$ animals in which coimmunoprecipitation was not observed (Fig. 1D,E). To determine the relative contribution of R7BP and GPR158 to controlling RGS7, we compared the expression of RGS7 directly in hippocampi of R7BP and GPR158 KOs (Fig. 2A,B). We further generated R7BP and GPR158 DKO line to evaluate possible redundancy and interdependence of the respective adaptor subunits. The DKO mice were viable and did not show overt issues with development. Consistent with previous observations (Orlandi et al., 2015), deletion of GPR158 significantly reduced RGS7 content (to $66 \pm 7 \%$ of WT levels). The effect of R7BP ablation was much smaller (to $86 \pm 3 \%$ ) and did not reach our criteria for significance (Fig. 2A,B). Interestingly, concurrent deletion of both R7BP and GPR158 resulted in a stronger reduction in RGS7 levels to $50 \pm 9 \%$ relative to WT (Fig. $2 A, B$ ). We did not detect any significant differences in the expression of other components of the RGS7 complex and $\mathrm{GABA}_{\mathrm{B}}$ signaling pathway: $\mathrm{G} \alpha_{\mathrm{o}}, \mathrm{G} \beta 5$, $\mathrm{GABA}_{\mathrm{B}}$ R2, GIRK1, and GIRK2 (Fig. $2 A, B$ ), indicating selective effects of adaptor ablation on RGS7 complex stability.

We next examined the relative contributions of R7BP and GPR158 to membrane targeting of RGS7 by performing subcellular fractionation of hippocampal tissues from individual KOs compared with DKO. We found that both R7BP and GPR158 each significantly contributed to membrane association of RGS7 as judged by the reduction in RGS7 membrane content in respective KOs (Fig. 2C). Quantification of absolute content of RGS7 on the membrane from Western blotting data calibrated against recombinant RGS7 protein standards spiked into RGS7 KO samples revealed that the effect of GPR158 ablation was greater than that of R7BP ablation: reducing content of membrane RGS7 to $83 \pm 2 \%$ and $50 \pm 4 \%$, respectively (Fig. $2 D, E$ ). Interestingly, only barely detectable $9 \pm 4 \%$ of RGS7 remained on the membranes from DKO hippocampi (Fig. 2C-E). These results suggest that GPR158 and R7BP together account for the vast majority of membrane targeting of RGS7 in hippocampal neurons, with GPR158 providing a greater contribution.

We further confirmed these observations while examining precise subcellular distribution of RGS7 in hippocampal pyrami- 
A

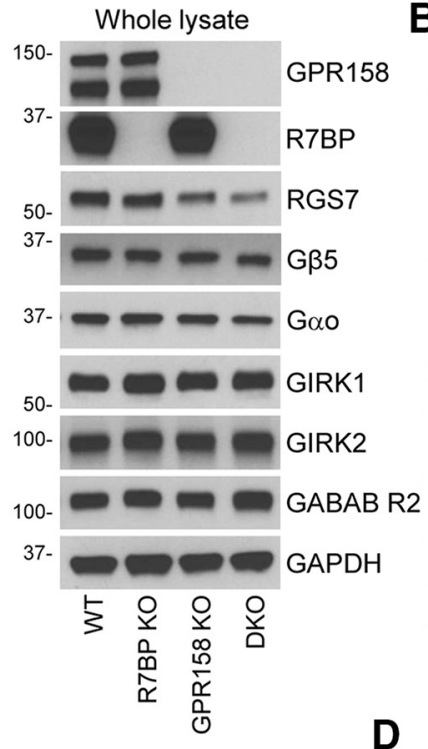

C

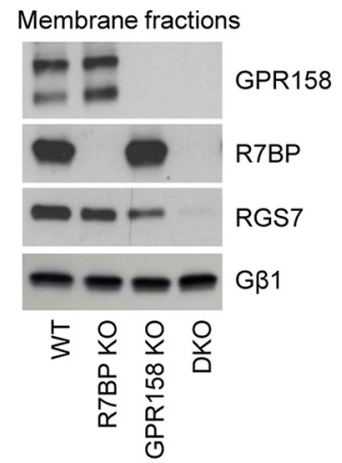

B

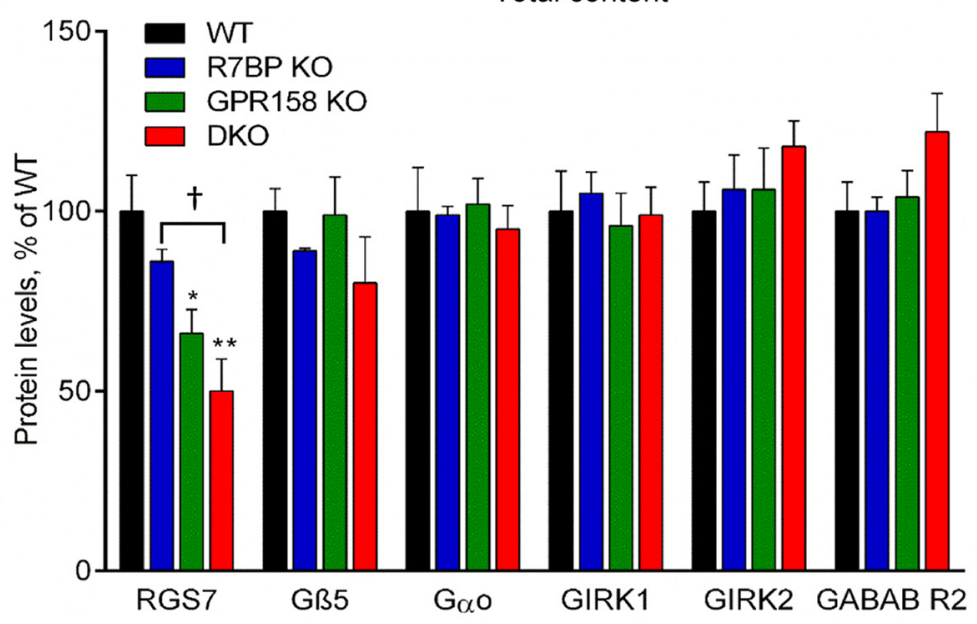

D Absolute quantification of RGS7 levels

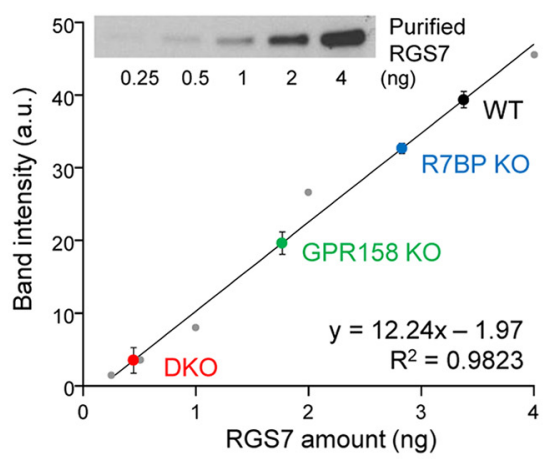

E

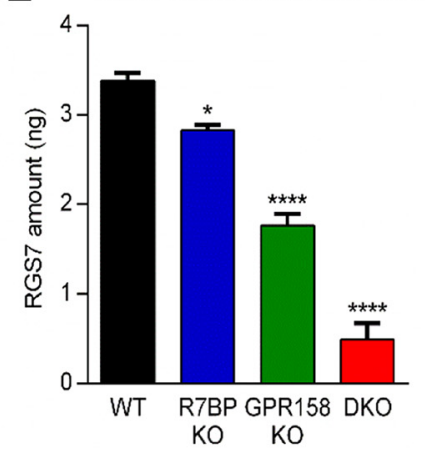

Figure 2. RGS7 levels and membrane localization in hippocampus are affected by ablation of its membrane anchors. $\boldsymbol{A}, \boldsymbol{B}$, Representative Western blots $(\boldsymbol{A})$ and quantification $(\boldsymbol{B})$ comparing the expression levels of several signaling proteins in total lysate of hippocampus from R7BP K0, GPR158 K0, and GPR158/R7BP DK0 mice compared with WT animals. Asterisks indicate statistically significant difference compared with WT. Error bars indicate SEM, ${ }^{*} p<0.05,{ }^{* *} p<0.01, n=4$ animals for each group, one-way ANOVA with Tukey multiplecomparisons test. †Significant difference in total RGS7 levels between R7BP KO and DKO $(p=0.0254)$. C, Representative Western blots of membrane preparations of hippocampus from WT, R7BP K0, GPR158 K0, and GPR158/R7BP DK0. G $\beta 1$ was used as a loading control. D, Amount of RGS7 present in the membrane fraction calculated using a standard curve with known amount of purified RGS7 diluted in RGS7 KO hippocampus lysate. $E$, Absolute membrane quantification of RGS7 levels at the plasma membrane in the four genotypes. Statistically significant differences compared with WT are reported. Error bars indicate SEM, ${ }^{*} p<0.05,{ }^{* * *} p<0.0001, n=4$ animals for each group, one-way ANOVA with Tukey's multicomparisons test.

dal neurons using an electron microscopy immunogold labeling technique (Fig. 3). Consistent with a previous report (FajardoSerrano et al., 2013), we found RGS7 to be positioned mostly on the plasma membrane across major neuronal compartments: dendritic shafts and spines as well as axonal terminals (Fig. $3 A-C$, $G-I$ ). In contrast, in DKO, most of RGS7 immunolabeling was confined to intracellular sites, in good quantitative agreement with our biochemical fractionation data (Fig. 3D-I).

RGS7 is the sole contributor to regulation of sIPSC kinetics by G $\beta 5$-containing GAP complexes

To begin comparing the contributions of auxiliary subunits to RGS7-mediated regulation of $\mathrm{GABA}_{\mathrm{B}}$-GIRK signaling, we first defined the role of RGS7 in controlling inhibitory signaling in CA1 pyramidal neurons. We previously found that $\mathrm{KO}$ of G $\beta 5$ subunit, which eliminates the expression of four RGS complexes containing RGS6, RGS7, RGS9, and RGS11 dramatically slows down the recovery phase of IPSCs (slow IPSCs, sIPSCs) (Xie et al., 2010), a major form of $\mathrm{GABA}_{\mathrm{B}}$-mediated inhibitory synaptic inputs onto CA1 neurons (Lüscher et al., 1997). To determine how much of this effect is mediated by RGS7, we studied sIPSC kinetics evoked in hippocampal slices comparing RGS7 KO side by side with WT littermates and $G \beta 5 \mathrm{KO}$ mice.

Stimulation of interneuron projections in stratum lacunosum moleculare (Fig. 4A) elicited outward currents of similar amplitudes in CA1 neurons of $G \beta 5 \mathrm{KO}, R G S 7 \mathrm{KO}$ and WT slices (Fig. $4 B, C)$. We confirmed that the sIPSC currents were largely mediated by GIRK because treatment with tertiapin Q abolished these synaptically evoked events (data not shown). We observed a drastic slowing of both activation and decay kinetics of sIPSC in RGS7 $\mathrm{KO}$. The response reached the peak significantly later in $R G S 7 \mathrm{KO}$ compared with WT, reflected in an increase in time-to-peak (Fig. $4 B, D)$. Furthermore, there was an $\sim 5$-fold increase in decay constant in slices lacking RGS7 (Fig. 4B,E). Importantly, the RGS7 $\mathrm{KO}$ phenotype was quantitatively indistinguishable from $G \beta 5$ $\mathrm{KO}$ when results were analyzed in parallel (Fig. $4 B-E$ ). These results reveal that RGS7 is the sole physiological regulator of $\mathrm{GABA}_{\mathrm{B}}$-GIRK signaling that drives sIPSC among the members of G $\beta 5$-containing R7 family RGS complexes. 

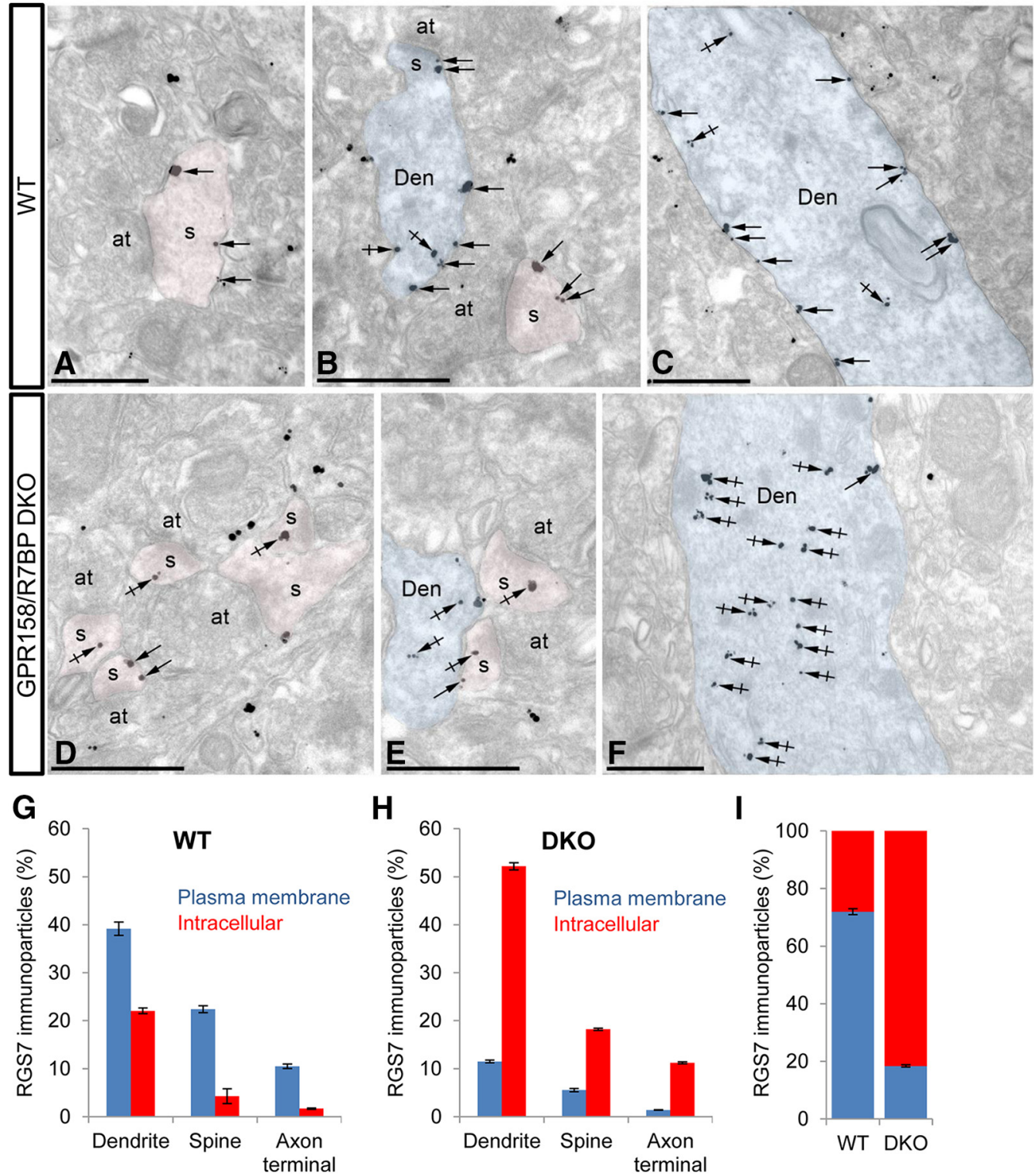

Figure 3. Change in subcellular localization of RGS7 in the hippocampus of mice lacking GPR158 and R7BP. $\boldsymbol{A}-\boldsymbol{F}$, Electron micrographs of the stratum radiatum of the hippocampal CA1 region showing immunoparticles for RGS7 detected using a preembedding immunogold method. Dendrites are outlined in blue and spines are colored in red. Dendritic shafts (Den), dendritic spines ( $s$ ), and axon terminals (at) are marked. In WT controls ( $\boldsymbol{A}-\boldsymbol{C}$ ), immunoparticles for RGS7 were mainly detected along the extrasynaptic plasma membrane (arrows) of dendritic shafts (Den) and spines ( $s$ ) and at low levels at intracellular sites (crossed arrows) in these compartments. In GPR158/R7BP DKO (D-F), immunoparticles for RGS7 were detected along the extrasynaptic plasma membrane (arrows) of dendritic shafts (Den) and spines (s), but more frequently observed at intracellular sites (crossed arrows) in these compartments. Scale bars, $0.5 \mu$ m. G-I, Quantification of RGS7 immunoparticle distribution across neuronal compartments in WT and DKO samples.

\section{R7BP, but not GPR158, regulates sIPSC kinetics}

Given the indispensable and large contribution of RGS7 to the regulation of sIPSC kinetics, we next compared the effects of genetic loss of its adaptor subunits, R7BP and GPR158. We found that sIPSCs in R7BP KO slices showed significantly decelerated kinetics of both activation as evidenced by increased peak latency and deactivation as reflected by the increased deactivation time constant (Fig. 5A,C,D). This effect, however, was smaller than that seen in $G \beta 5 \mathrm{KO}$ or $R G S 7 \mathrm{KO}$, suggesting that R7BP is responsible for regulating only a fraction of RGS7 actions in this process. Strikingly, we observed no differences in sIPSC kinetics between WT and GPR158 KO neurons. We also did not find any differences in the response amplitudes across all genotypes. Because compensation by R7BP may mask a possible effect of GPR158, we further analyzed the responses in the DKO mice compared with R7BP KO littermates (Fig. 5B-E). We did not detect appreciable differences in any response parameters between R7BP KO and DKO, suggesting that GPR158 does not shape sIPSCs even in the absence of regulatory R7BP influence.

\section{GPR158 does not regulate $\mathrm{GABA}_{\mathrm{B}} \mathrm{R}-\mathrm{GIRK}$ kinetics}

We have previously demonstrated that RGS7 and R7BP regulate the kinetics of GIRK channel deactivation in primary hippocampal pyramidal neurons (Ostrovskaya et al., 2014). Therefore, we next studied the effects of GPR158 ablation on GIRK-mediated responses driven by $\mathrm{GABA}_{\mathrm{B}} \mathrm{R}$ activation also in this system, which offers greater sensitivity and mechanistic precision. We further compared GIRK properties measured in neurons of GPR158 KO mice with those from $R 7 B P \mathrm{KO}$ and DKO evaluated in parallel. A saturating concentration of $\mathrm{GABA}_{\mathrm{B}}$ agonist baclofen evoked 
A

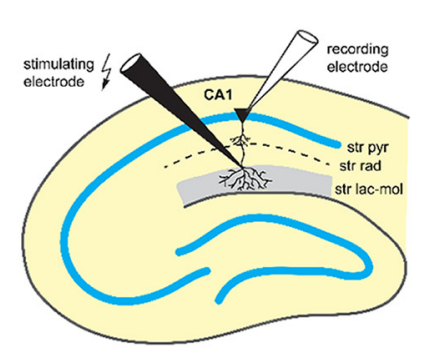

B

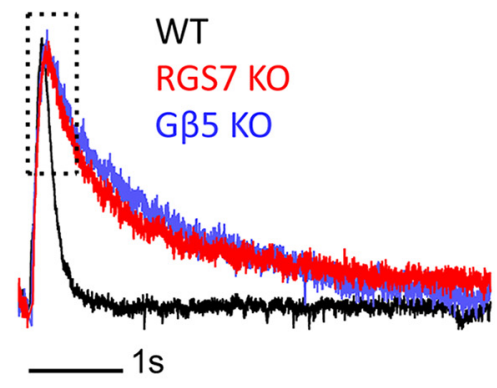

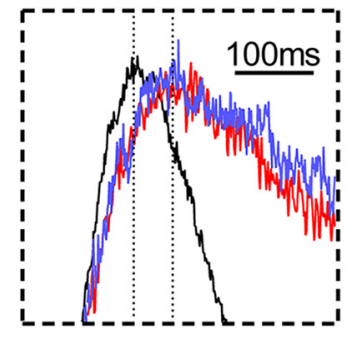

E
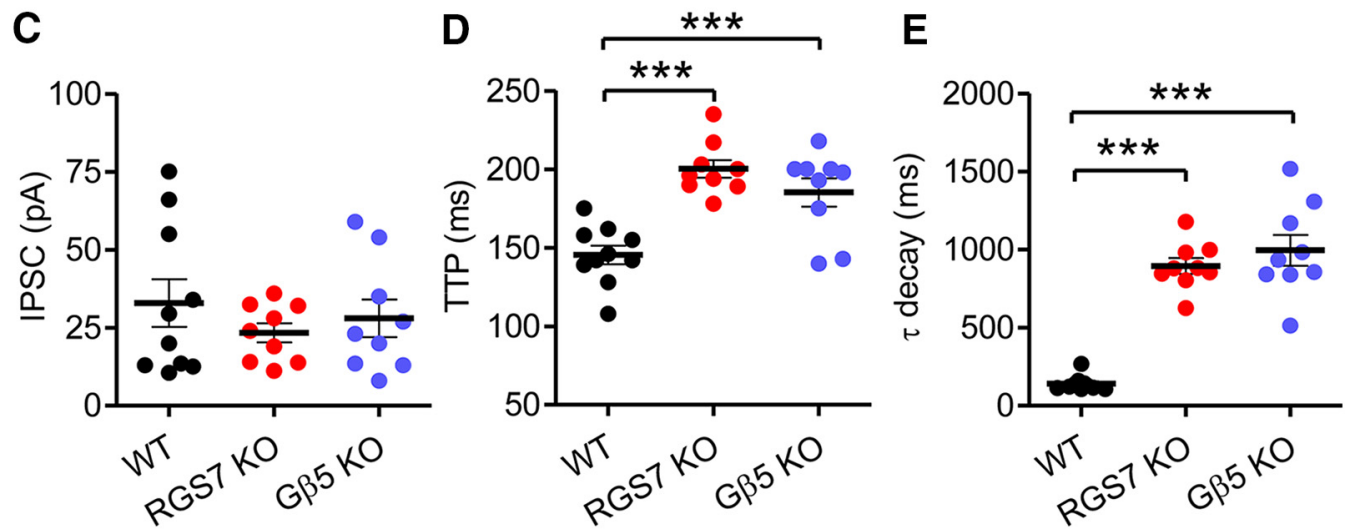

Figure 4. RGS7 regulates sIPSC kinetics. $A$, Schematic of the experimental strategy. The sIPSCS were recorded in CA1 neurons while evoking GABA release from interneurons by placing the stimulation electrode on the border of stratum radiatum and stratum lacunosum moleculare along the apical dendrites. $B$, Representative normalized traces of sIPSCs evoked by $400 \mu A$ biphasic stimulating current from WT (RGS7 ${ }^{+/+}$littermates), RGS7 K0, and G $\beta 5$ KO hippocampal slices (left). Inset, Peak region of sIPSCS (right). C, Average sIPSC amplitudes in WT, RGS7 K0, and G $\beta 5$ K0. $D$, Deactivation time constant determined via single-exponential fitting of response traces in $\mathrm{RGS7} \mathrm{KO}$ and $\mathrm{G} \beta 5 \mathrm{KO}$ versus $W T\left({ }^{* * *} p<0.001\right.$ vs WT, one-way ANOVA with Bonferroni's post tests, $n=$ $9-10)$. $E$, Response onset timing determined as time to peak (TTP) values in RGS7 KO and G $\beta 5$ KO (***p $<0.001$ DKO vs WT).

GIRK currents with slowed deactivation in R7BP KO. However, the response recorded in GPR158 KO neurons was indistinguishable from WT (Fig. 6A,B). Furthermore, GIRK current deactivation kinetics in DKO neurons was slower than in WT, but did not differ from that in $R 7 B P \mathrm{KO}$ (Fig. $6 A, B$ ). Other parameters of baclofen-evoked currents, amplitudes, activation, and desensitization rates, were similar in all genotypes (Fig. $6 C-E$ ). These findings suggest that GPR158 does not contribute to $\mathrm{GABA}_{\mathrm{B}}$ GIRK signaling in hippocampal pyramidal neurons.

\section{Recovery of $\mathrm{Ca}^{2+}$ channels from $\mathrm{GABA}_{\mathrm{B}} \mathrm{R}$-mediated} inhibition is facilitated by RGS7/R7BP complexes

Because the regulation of N/P/Q types of $\mathrm{Ca}^{2+}$ channels constitutes the second major branch of $\mathrm{GABA}_{\mathrm{B}}$ signaling, we next probed the contribution of RGS7 complex to this process, which has not been defined before. We used primary hippocampal neuron system to record voltage-gated $\mathrm{Ba}^{2+}$ currents in RGS7 KO, $R 7 B P \mathrm{KO}, G P R 158 \mathrm{KO}$, and WT. Depolarizing voltage steps from holding potential of $-70 \mathrm{mV}$ elicited family of currents characteristic of the $\mathrm{Ca}^{2+}$ channels, with no difference in current density and voltage dependence between the genotypes (Fig. $7 A, B$ ). Next, we assessed the magnitude and speed of baclofen-mediated block onset and relief upon rapid agonist application and removal. To increase the frequency of steps from -70 to $-10 \mathrm{mV}$, we shortened the pulse duration to $12 \mathrm{~ms}$ and recorded the sweeps every $2 \mathrm{~s}$ (Fig. 7C), an approach reported previously (Greif et al., 2000). The amplitude of the current was taken 10-12 ms after the onset of the voltage step to $-10 \mathrm{mV}$ and was within $90-100 \%$ of the peak current estimated compared with currents recorded for the $I-V$ relationship. Application of $100 \mu \mathrm{M}$ baclofen caused a pronounced decrease in current amplitude with no significant differences between genotypes (64.8 $\pm 3.4 \%$ in WT vs $64.2 \pm 3.3 \%$ in $R G S 7 \mathrm{KO}, 63.3 \pm 4.1 \%$ in $R 7 B P \mathrm{KO}, 69.7 \pm 3.8 \%$ in GPR158 KO) (Fig. 7C,D). The densities of the current portions blocked by baclofen were also not different among the genotypes (Fig. 7E). These results show that RGS7, R7BP, and GPR158 do not affect the $\mathrm{Ca}_{\mathrm{V}}$ abundance on the membrane and the magnitude of its inhibition by baclofen. To study the kinetic aspects of channel modulation by $\mathrm{GABA}_{\mathrm{B}}$ Rs, we used a fast perfusion system to apply and wash out baclofen (Fig. $7 F$ ). Although the timing of the baclofen-mediated inhibition onset could not be accurately quantified due to its fast speed, we observed that RGS7 $\mathrm{KO}$ neurons showed a significant delay in the current return to control levels after baclofen washout (Fig. $7 F-H$ ). The half-times $\left(T_{1 / 2}\right)$ of recovery were $2.4 \pm 0.2$ and $5.0 \pm 0.8 \mathrm{~s}$ in WT versus RGS7 KO, respectively (Fig. $7 H$ ). Having established that RGS7 controls the timing of $\mathrm{Ca}_{\mathrm{V}}$ inhibition by $\mathrm{GABA}_{\mathrm{B}}$, we next evaluated the contributions of its subunits GPR158 and R7BP to this process in neurons obtained from GPR158 KO and R7BP KO mice. We found a significant delay in recovery of $\mathrm{Ca}_{\mathrm{V}}$ currents from $\mathrm{GABA}_{\mathrm{B}}$-mediated inhibition in $R 7 B P \mathrm{KO}\left(T_{1 / 2}\right.$ of $3.8 \pm$ $0.4 \mathrm{~s}$ ) compared with WT neurons (Fig. $7 I-K)$. This effect was smaller compared with RGS7 deletion, indicating that, as with GIRK regulation, R7BP controls only a fraction of RGS7 activity on the channel. In contrast, we observed no difference between WT and GPR158 KO (Fig. 7K), indicating that GPR158 does not affect the timing of $\mathrm{GABA}_{\mathrm{B}}$-mediated regulation of $\mathrm{Ca}_{\mathrm{V}}$ channels. 
A

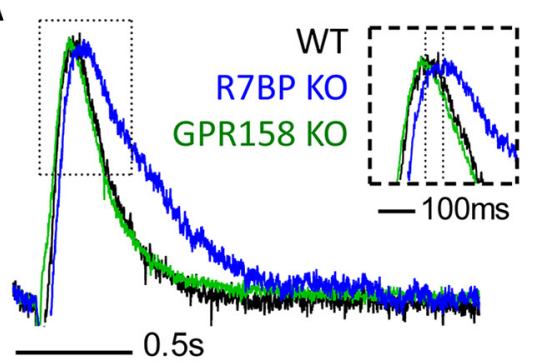

B

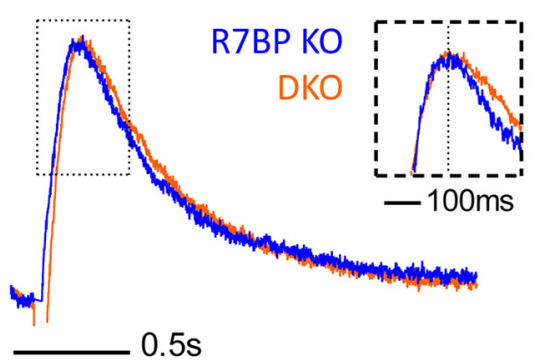

C

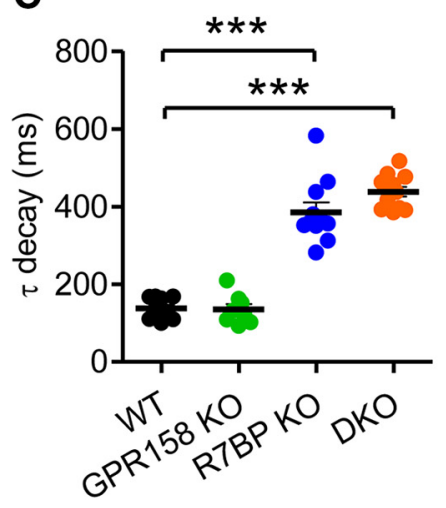

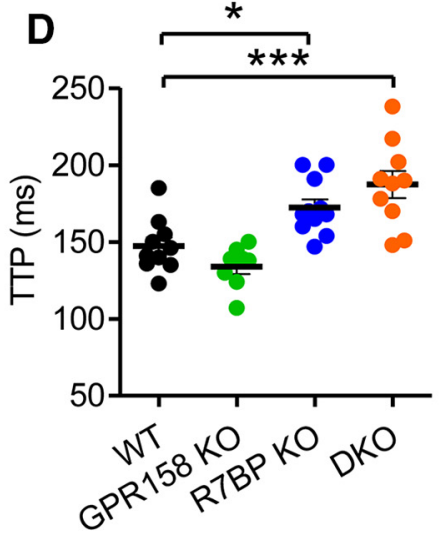

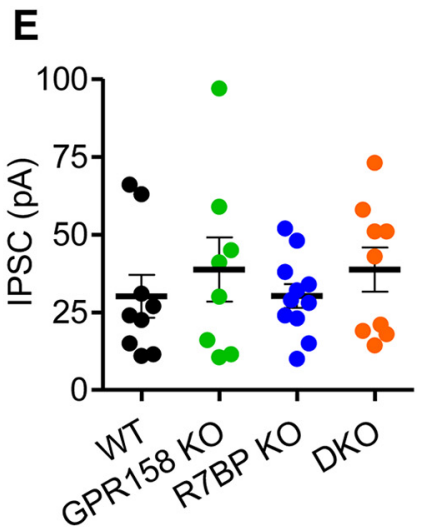

Figure 5. R7BP, but not GPR158, regulates sIPSC kinetics. $\boldsymbol{A}, \boldsymbol{B}$, Representative normalized traces of sIPSCs from WT (GPR158 ${ }^{+/+}$), GPR158 K0, and R7BP K0 cross-compared against their respective control littermates. The sIPSCs were elicited and recorded in hippocampal slices as described in Figure 4. The insets show the peak region of sIPSCs. Dashed lines mark the position of the peaks. C, Deactivation time constant determined via single-exponential fitting of response traces in GPR158 KO, R7BP K0, DKO, and WT (*** $<<0.001$ vs WT, one-way ANOVA with Bonferroni's post tests, $n=8-12)$. D, Response onset timing determined as time to peak (TTP) values in GPR158 KO, R7BP K0, DKO, and WT ( ${ }^{*} p<0.05$ R7BP KO vs WT, ${ }^{* * *} p<0.001$ DKO vs WT). E, Average sIPSC amplitudes in GPR158 KO, R7BP KO, DKO, and WT.

\section{GPR158 opposes the function of R7BP in accelerating $\mathrm{GABA}_{\mathrm{B}} \mathrm{R}$-GIRK kinetics}

The lack of GPR158 effect on modulation of $\mathrm{GABA}_{\mathrm{B}}$ signaling to $\mathrm{Ca}_{\mathrm{V}}$ and GIRK channels suggests that RGS7 complexed with it may be excluded from participating in this process. To test this possibility directly, we studied the effect of GPR 158 overexpression on $\mathrm{GABA}_{\mathrm{B}}$ signaling through GIRK and $\mathrm{Ca}_{\mathrm{V}}$ channels. Infecting primary neurons with adenovirus carrying GPR158 (Fig. $8 A$ ) resulted in elevation of GPR158 protein levels detectable by both Western blotting and immunohistochemistry (Fig. 8B,C). The concurrent EGFP expression encoded by the same vector was used to identify positively transduced neurons. In control experiments, cultures were infected with adenovirus carrying EGFP only (Fig. $8 B, C$ ). Electrophysiological recordings of GIRK currents from fluorescent neurons infected with AV-GPR158 showed a significant increase in deactivation rate of the response compared with those infected with empty AV-EGFP virus (Fig. $8 D, E)$. Accordingly, quantification revealed a prominent increase in $\tau$ deactivation from $1226 \pm 104 \mathrm{~ms}$ in control neurons to $2240 \pm 202 \mathrm{~ms}$ in neurons overexpressing GPR158 (Fig. 8E).

Similar observations were made when studying modulation of $\mathrm{Ca}_{\mathrm{V}}$ currents, in which we measured the effect of GPR158 overexpression on the timing of relief from baclofen inhibition (Fig. $8 F-J)$. Again, we detected no differences in the density of total $I_{\text {Ва }}$ currents across voltage steps (Fig. $8 F$ ) or the fraction blocked by baclofen (Fig. $8 G$ ), indicating unaffected expression and targeting of $\mathrm{Ca}_{V}$ to the plasma membrane. In contrast, we observed significantly slower current recovery in neurons infected with AV-GPR158, in which $T_{1 / 2}$ was $3.1 \pm 0.1 \mathrm{~s}$ compared with $2.3 \pm$ $0.2 \mathrm{~s}$ in neurons infected with AV-EGFP control virus (Fig. $8 \mathrm{H}-$ $J$ ). Together, these findings indicate that GPR158 overexpression negatively affects the ability of RGS7 to regulate the kinetics of $\mathrm{GABA}_{\mathrm{B}}$ signaling to GIRK and $\mathrm{Ca}_{\mathrm{V}}$ ion channels without affecting $\mathrm{Ca}_{\mathrm{V}}$ expression and localization.

\section{Discussion}

The key observation reported in this study is that the macromolecular composition of major neuronal G-protein regulator, the RGS7 complex, determines its ability to influence downstream effectors (Fig. 9). Specifically, our findings indicate that R7BP, but not GPR158, modulates RGS7 effect on $\mathrm{GABA}_{\mathrm{B}} \mathrm{R}$ regulation of ion channels, GIRK, and $\mathrm{Ca}_{\mathrm{v}} 2$. Moreover, shifting the balance toward the formation of RGS7-GPR158 complexes results in the loss of the RGS7 influence on these signaling pathways. Along with this central message, novel findings reported in this study include: (1) RGS7 is the sole member of R7 family that regulates $\mathrm{GABA}_{\mathrm{B}} \mathrm{R}$ signaling to GIRKs and sIPSCs in the hippocampal CA1 pyramidal neurons, (2) RGS7 also substantially affects the modulation of the $\mathrm{Ca}_{\mathrm{V}} 2$ current by $\mathrm{GABA}_{\mathrm{B}} \mathrm{Rs}$, and (3) $\mathrm{GABA}_{\mathrm{B}} \mathrm{R}$ mediated effects on ion channels are selectively mediated by R7BP-RGS7, but not GPR158-RGS7 complexes.

Previous studies have shown that regulation of GIRK channels by $\mathrm{GABA}_{\mathrm{B}}$ is substantially affected by members of the R7 family of RGS proteins (RGS6, RGS7, RGS9, and RGS11) that exist as constitutive complexes with the central scaffolding subunit $G \beta 5$ (Xie et al., 2010; Maity et al., 2012; Ostrovskaya et al., 2014). KO of $G \beta 5$ that eliminates all R7 RGS proteins drastically increases the sensitivity of GIRK modulation by $\mathrm{GABA}_{\mathrm{B}}$ and slows down its deactivation kinetics. In hippocampal neurons, KO of RGS7, but not RGS6, resulted in a similar phenotype (Ostrovskaya et al., 2014), whereas the contributions of other R7 RGS proteins remained unclear. By direct side-by-side comparison of G $\beta 5$ and 

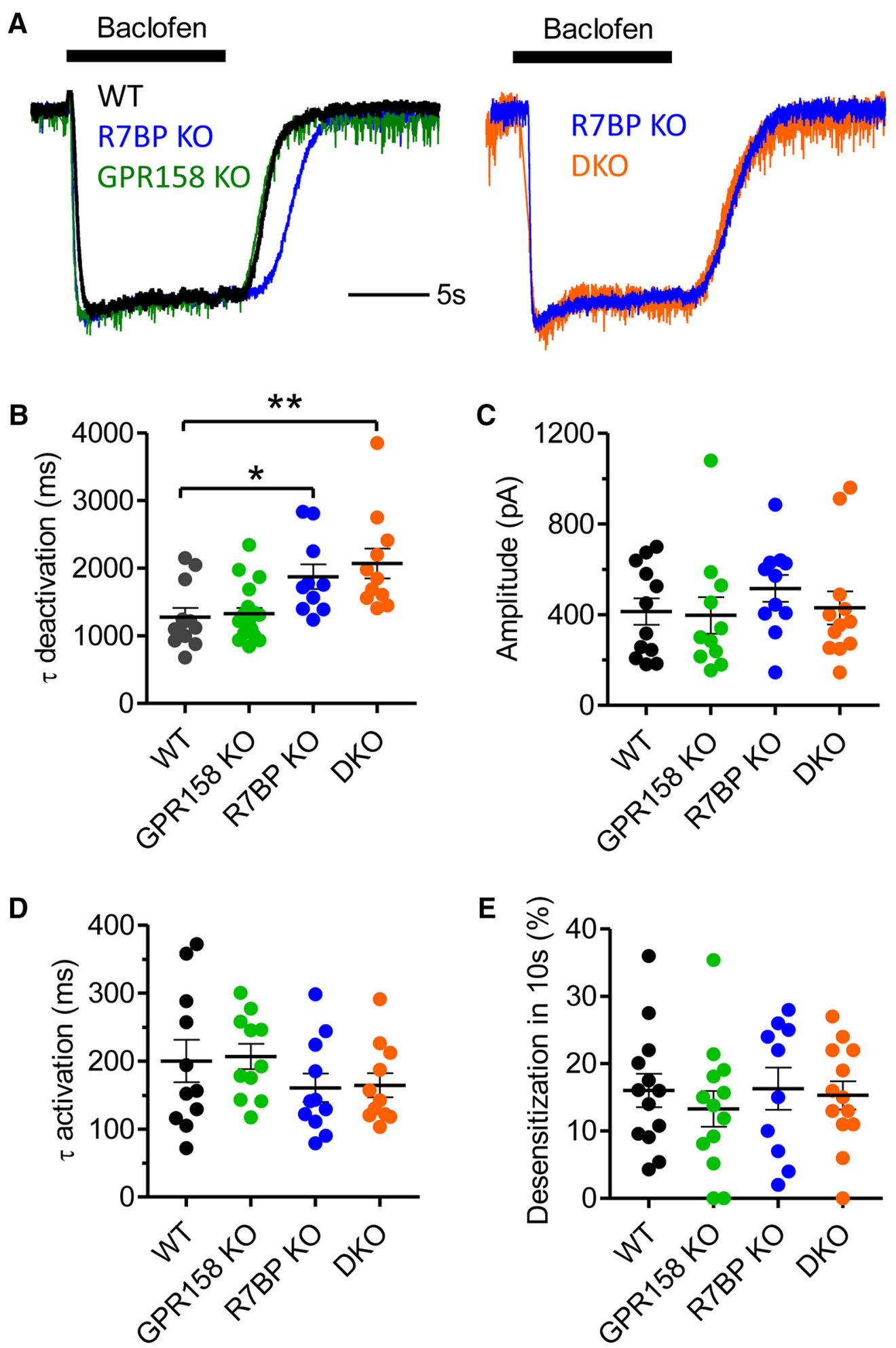

Figure 6. R7BP, but not GPR158, regulates the kinetics of $\mathrm{ABBA}_{B}$-mediated GIRKs in primary hippocampal neurons. $A$, Representative normalized traces of GIRKs evoked by baclofen $100 \mu \mathrm{m}$ from WT (GPR158 ${ }^{+/+}$), GPR158 KO, and R7BP KO (left); R7BP K0 and DKO (right). B, Deactivation time constant in GPR158K0, R7BP KO, DK0, and WT ( ${ }^{*} p<0.05$ R7BP K0 vs WT, * $p<0.01$ DK0 vs WT, one-way ANOVA with Bonferroni's post tests). $\boldsymbol{C}-\boldsymbol{E}$, Amplitudes ( $\boldsymbol{C}$, activation (D), and desensitization (E) rates in GPR158K0, R7BP K0, DK0, and WT $(p>0.05, n=10-15)$.

RGS7 KOs, measuring GIRK kinetics in primary neurons and GIRK-mediated sIPSCs in brain slices, we documented complete phenotypic equivalency of G $\beta 5$ and RGS7 elimination, thus establishing RGS7 as the sole R7 RGS involved in the regulation of $\mathrm{GABA}_{\mathrm{B}}$-GIRK signaling. We next addressed the contribution of membrane targeting of RGS7 complex to its effects. Because
RGS7 is a soluble protein, its ability to regulate membrane delimited $\mathrm{GABA}_{\mathrm{B}}$-GIRK was thought to require the action of membrane-targeting adaptors. Accordingly, elimination of its membrane anchor R7BP resulted in similar phenotype seen upon RGS7 elimination, although to a significantly lesser extent (Zhou et al., 2012; Ostrovskaya et al., 2014). Interestingly, biochemical 

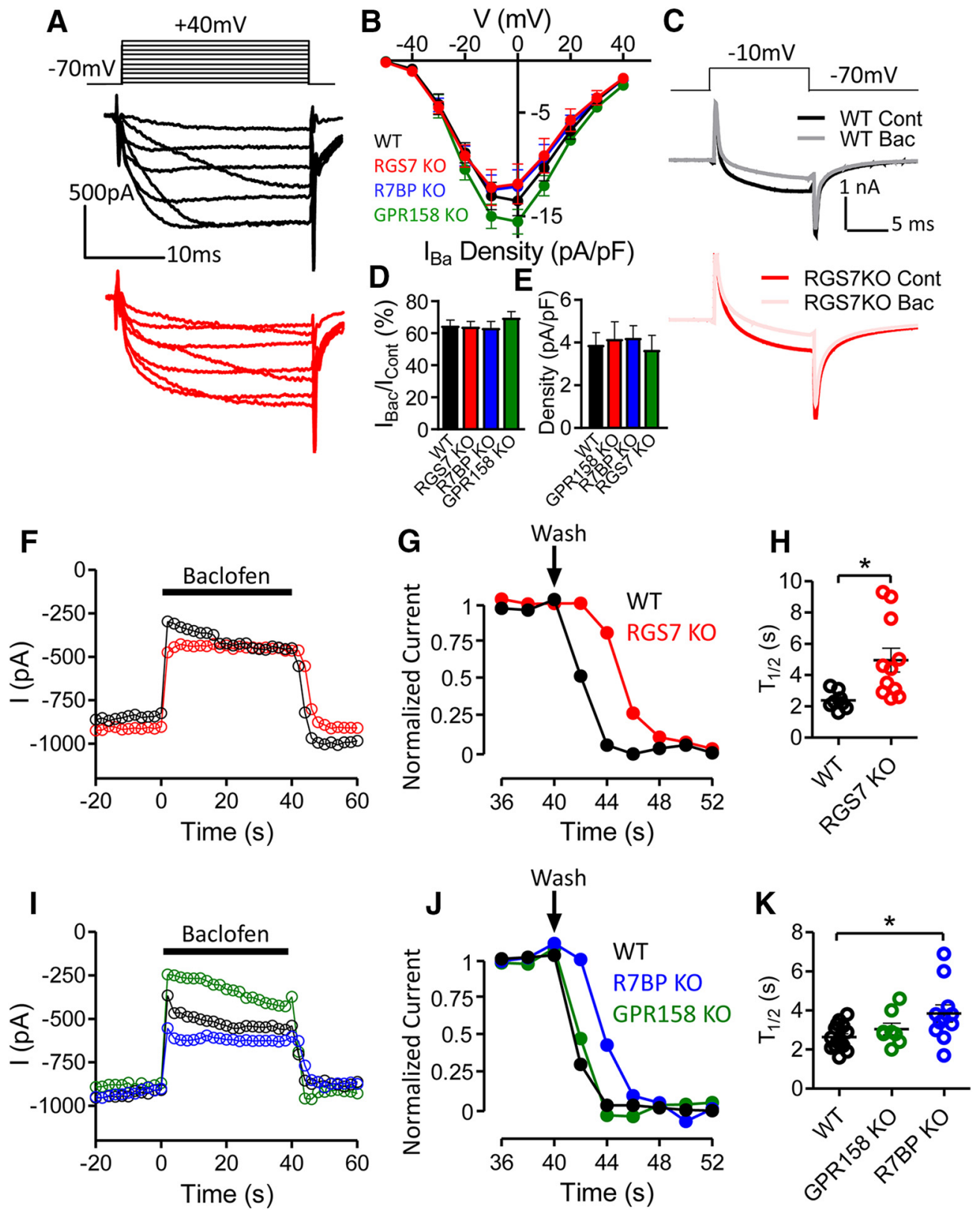

Figure 7. RGS7 and R7BP, but not GPR158, regulate the kinetics of $G_{A B A}$-mediated regulation of $C_{V} 2$ channels in primary hippocampal neurons. $A$, Representative traces of $I_{B a}$ in WT $\left(\mathrm{RGS7}^{+/+}\right)$and RGS7 K0 evoked by depolarizing voltage steps from a holding potential of $-70 \mathrm{mV}$ to up to $+40 \mathrm{mV}$. The inset shows time course and amplitudes of the steps. $\boldsymbol{B}$, Average $I-V$ relationship curves for WT, RGS7 KO, R7BP K0, and GPR158 K0. Current density at end of $25 \mathrm{~ms}$ pulse is plotted versus membrane potential. Pulses were applied every $8 \mathrm{~s}$ from a holding potential of $-70 \mathrm{mV}$ to up to $+40 \mathrm{mV}$ in $10 \mathrm{mV}$ increments (density $F_{(5,48)}=0.9868, p>0.05$, two-way repeated-measures ANOVA with Sidak's post tests, $\left.n=7-10\right)$. $C$, Representative traces of $I_{\text {Ba }}$ before and after application of baclofen $100 \mu \mathrm{m}$ in WT and RGS7 KO.D,E, Residual current fraction of I $_{\mathrm{Ba}}$ after baclofen application (D) and density of the blocked current fraction after baclofen application, $I_{\text {Cont }}-I_{\text {Bac }}(E)$ in WT and KOs $(p>0.05$ vs WT, one-way ANOVA with Bonferroni's post tests, $n=7-13)$. $F$, Representative experiments showing time course of baclofen inhibition of $I_{B a}$ for WT and RGS7 KO cells. Maximal amplitudes of $I_{B a}$ sweeps of $12 \mathrm{~ms}$ duration evoked every $2 \mathrm{~s}$ by steps to $-10 \mathrm{mV}$ are plotted versus time course. $G$, Time course of recovery from baclofen block from the experiments shown in $\boldsymbol{F}$. Amplitudes of the blocked $I_{B a}$ fraction were normalized. $\boldsymbol{H}$, Average recovery half-time $\left(T_{1 / 2}\right)$ from baclofen block in RGS7 KO versus WT cells $\left({ }^{*} p<0.05, t\right.$ test, $\left.n=8-11\right)$. $\boldsymbol{I}-\boldsymbol{K}$, As in $\boldsymbol{F}-\boldsymbol{H}$ but performed on WT (GPR158 ${ }^{+/+}$and RGS7 ${ }^{+/+}$combined), R7BP K0, and GPR158 KO ( ${ }^{*} p<0.05$, R7BP K0 vs WT, one-way ANOVA with Bonferroni's post tests, $n=8-15$ ).

analysis showed that elimination of R7BP brought about only a moderate decrease $(\sim 25 \%)$ in membrane content of RGS7 (Jayaraman et al., 2009; Panicker et al., 2010), prompting a hypothesis that another membrane adaptor compensates for R7BP loss. Indeed, such protein was subsequently identified to be GPR158 and its ablation alone eliminated a greater fraction $(\sim 50 \%)$ of RGS7 on the membrane (Orlandi et al., 2012, 2015), making it an ideal candidate for a missing redundant subunit functionally compensating in $\mathrm{GABA}_{\mathrm{B}}$-GIRK regulation when R7BP is lost. While formally testing this hypothesis, the current study resulted in a surprising conclusion: not only does GPR158 not functionally compensate for R7BP, it counteracts the effects of R7BP on GIRK. Quantitative biochemical experiments revealed that deletion of both R7BP and GPR158 synergistically removed the majority of RGS7 from the plasma membrane, indicating that GPR158 and R7BP compete for RGS7 binding and control distinct pools of it. We further confirmed that RGS7 indeed forms complexes with both GPR158 and R7BP by direct immunoprecipitation experiments. We think that these observations suggest that RGS7 may exist in two alternative configurations on the 
A

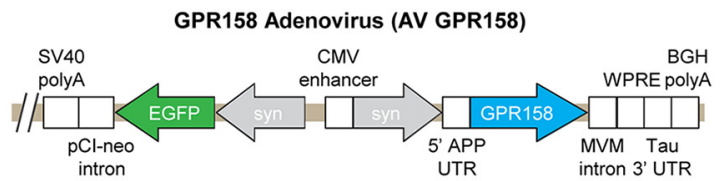

EGFP Adenovirus (AV GFP)

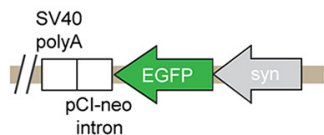

B
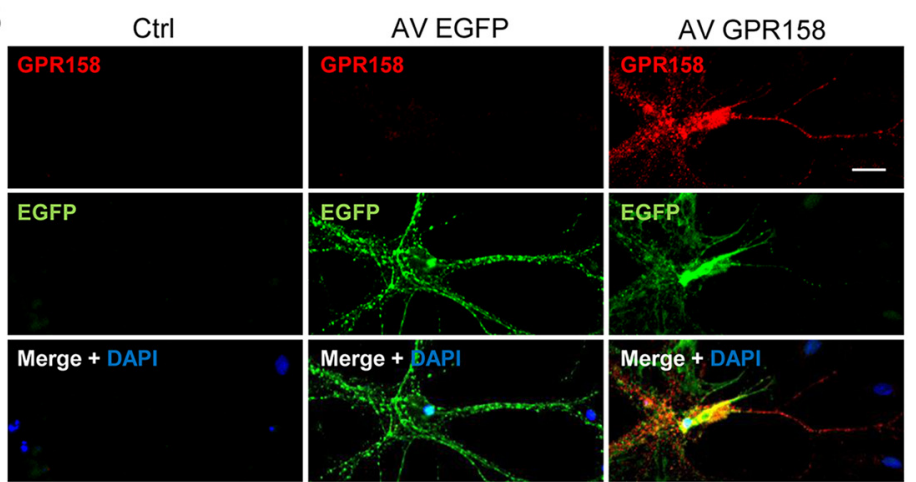

C
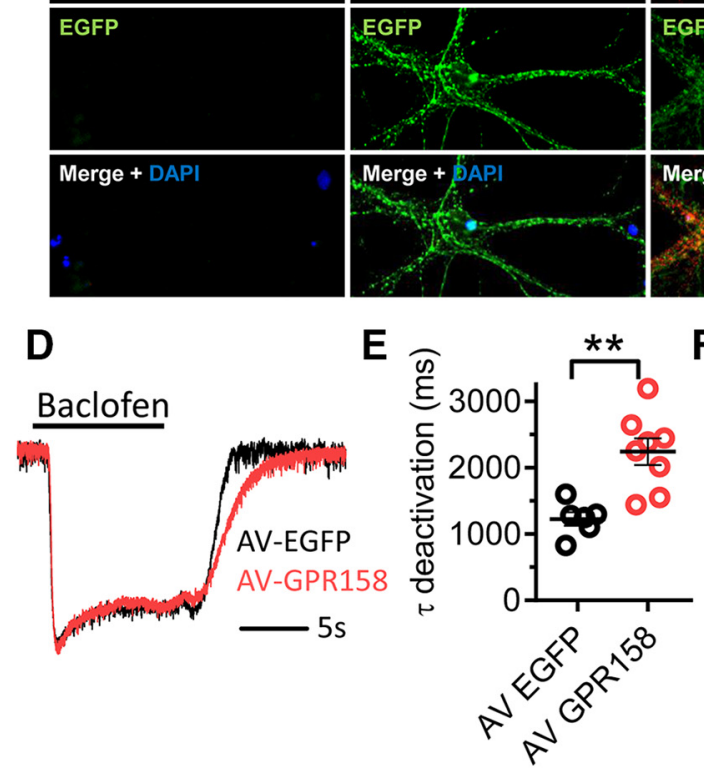

F $\quad \mathrm{V}(\mathrm{mV})$

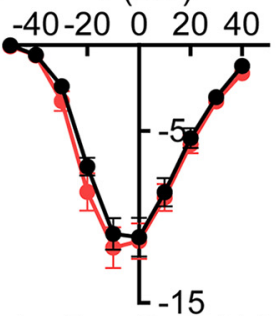

$\mathrm{I}_{\mathrm{Ba}}$ Density (pA/pF)

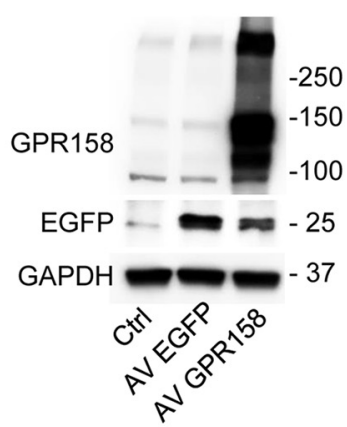

G
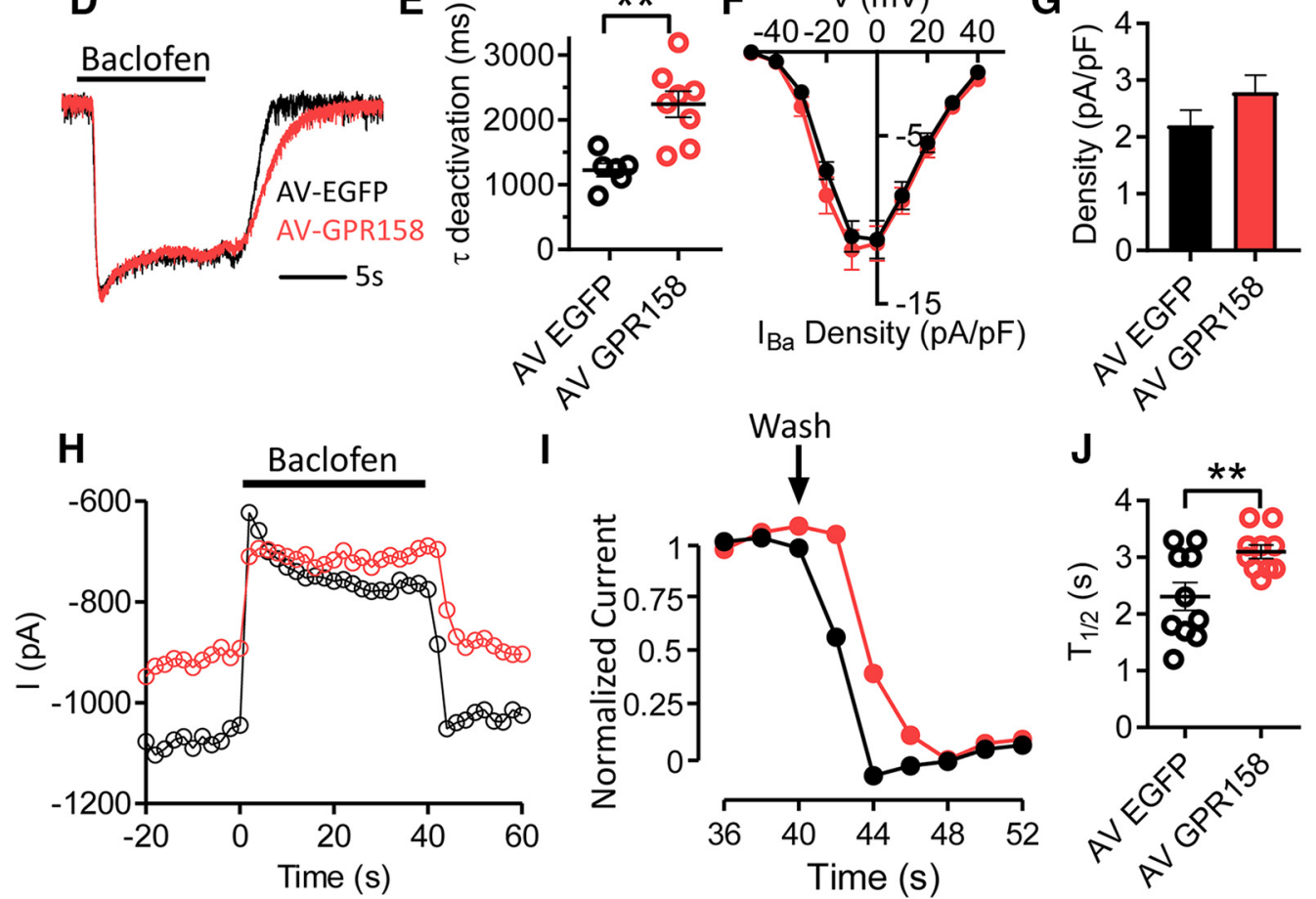

Figure 8. Viral overexpression of GPR158 inhibits RGS-mediated modulation of GIRK and $\mathrm{Ca}_{\mathrm{v}} 2$ channels. $\boldsymbol{A}$, Scheme of the viral constructs used in the experiments for GPR158 overexpression. $\boldsymbol{B}$, Analysis of GPR158 and EGFP expression in primary hippocampal cultures uninfected (Ctrl), infected with control virus (AV EGFP), or infected with GPR158-containing virus (AV GPR158) by immunocytochemistry followed by confocal microscopy. C, Western blot analysis of primary hippocampal culture uninfected, infected with AV EGFP, or infected with AV GPR158. Specific antibodies against EGFP or GPR158 were used. GAPDH was used as a loading control. $\boldsymbol{D}$, Representative normalized traces of GIRKs from neurons overexpressed with AV EGFP and AV GPR158. E, Deactivation time constant in AV EGFP and AV GPR158 ( ${ }^{* *} p<0.01$ vs WT, $t$ test, $n=6-8$ ). $F$, Average $/-V$ relationship curves for $~_{\text {Ba }}$ in AV EGFP and AV GPR158 cells $\left(\right.$ AV type $F_{(1,16)}=0.4079, p>0.05$, two-way repeated-measures ANOVA, $n=7-11)$. G, Density of the blocked current fraction after baclofen application in AV EGFP and AV GPR158 neurons $(p>0.05, t$ test, $n=11-12) . \boldsymbol{H}$, Representative experiments showing time course of baclofen inhibition of $\left.\right|_{\mathrm{Ba}}$ for AV EGFP and AV GPR158 cells. $I$, Time course of recovery from baclofen block from the experiments shown in $F$. Amplitudes of blocked $I_{\text {Ba }}$ fraction were normalized. $J, T_{1 / 2}$ in AV EGFP cells versus AV GPR158 $\left({ }^{* *} p<0.01, t\right.$ test, $\left.n=10\right)$.

plasma membrane and, although the complex with R7BP plays a permissive role in ion channel regulation, GPR158 prevents the action of RGS7 on GIRK. This inhibition could be explained by an occlusion mechanism in which GPR158 association simply makes RGS7 unavailable for binding to R7BP that normally facilitates GIRK regulation (Fig. 9). Alternatively, we cannot rule out that GPR158 instead selectively targets RGS7 to other intracellular effectors.

Our observations further suggest that a very small fraction of RGS7 remaining on the plasma membrane without R7BP and GPR158 is capable of effective GIRK regulation. The degree of this regulation is revealed by comparing RGS7 KO with R7BP/GPR158 DKO, which suggested that $~ 10 \%$ of "anchorfree” RGS7 is responsible for the majority of GIRK control exceeding the fraction regulated by RGS7-R7BP complex (revealed by comparing WT and R7BP KO). We think that the disproportionately large contribution of small RGS fraction remaining on the membrane in the absence of $\mathrm{R} 7 \mathrm{BP}$ and GPR158 is likely explained by direct association of RGS7/G $\beta 5$ with the GIRK (Xie et al., 2010), placing it in the immediate 


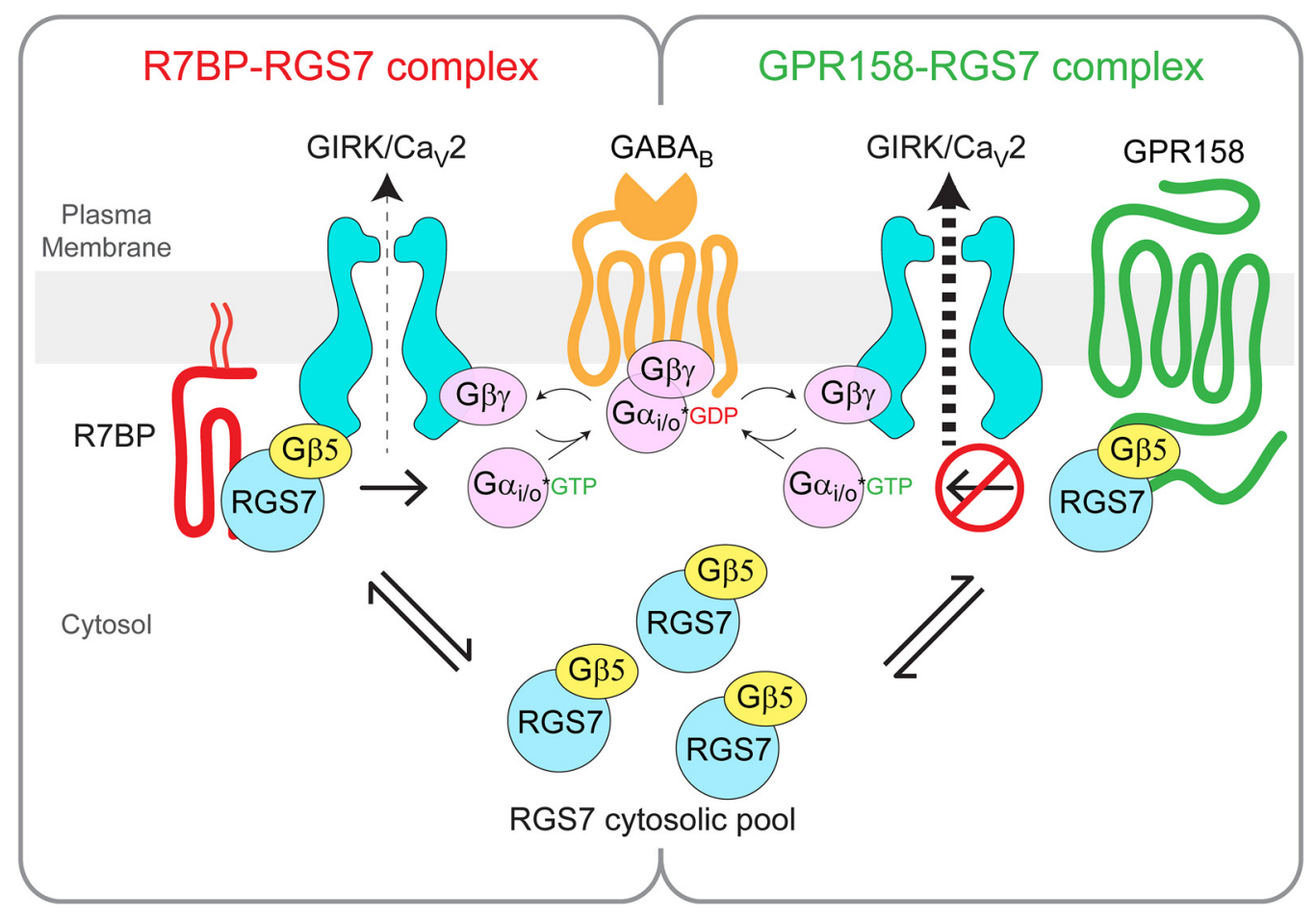

Figure 9. Proposed scheme for differential modulation of ion channels by macromolecular complexes of RGS7 with R7BP and GPR158. R7BP facilitates RGS7 recruitment to the plasma membrane, enhancing its ability to regulate $\mathrm{G} \beta \gamma$ subunits released upon activation of $\mathrm{G} \alpha \mathrm{i} / 0$ proteins by $\mathrm{GABA}_{\mathrm{B}}$ in the molecular vicinity of $\mathrm{GIRK}$ and $\mathrm{Ca}_{\mathrm{V}} 2$ channels. Transferring control of RGS7 to $\mathrm{GPR} 158$ prevents its ability to regulate $G A B A_{B}$ signaling to both GIRK and $C_{V} 2$. GPR158 and R7BP compete for the common pool of cytosolic RGS7/G $\beta 5$.

molecular vicinity of the channel and thus enhancing regulation of its target (Fig. 9).

Another major finding of this work is in the first-time implication of the RGS7 complex in the regulation of voltage-gated calcium channels of the P/Q and $\mathrm{N}$ types, $\mathrm{Ca}_{\mathrm{V}} 2.1 / \mathrm{Ca}_{\mathrm{V}} 2.2$. The $\mathrm{GABA}_{\mathrm{B}}$ Rs on cell bodies and presynaptic terminals also control the extent of their synaptic signaling via inhibition of the $P / Q / N$ $\mathrm{Ca}_{\mathrm{V}} 2 \mathrm{Ca}^{2+}$ channels and neurotransmitter release by $\mathrm{G} \beta \gamma$ liberated from PTX-sensitive $\mathrm{G} \alpha_{\mathrm{i} / \mathrm{o}}$ subunits (Holz et al., 1986; Doze et al., 1995; Dolphin, 2003). The role of RGS complexes in this process is less clear, with only few RGS proteins across the entire nervous system implicated in regulation of $\mathrm{Ca}_{\mathrm{V}} 2$-mediated calcium influx. For example, RGS2 and RGS3 disinhibit $\mathrm{Ca}_{\mathrm{V}} 2$ channels and increase transmitter release (Han et al., 2006; ToroCastillo et al., 2007), whereas RGS4 and RGS12 accelerate the time course of desensitization of norepinephrine-mediated current inhibition (Diversé-Pierluissi et al., 1999; Schiff et al., 2000). In this report, we reveal RGS7 to be a key player in regulation of $\mathrm{Ca}_{\mathrm{V}}$ function in hippocampal CA1 neurons. By accelerating the relief of $\mathrm{Ca}_{\mathrm{V}} 2$ current blockade upon termination of $\mathrm{GABA}_{\mathrm{B}} \mathrm{R}$ activation, RGS7 acts to lessen the effects of $\mathrm{GABA}_{B} \mathrm{R}$-mediated inhibition while increasing its temporal resolution. Because dynamic regulation of $\mathrm{Ca}_{\mathrm{V}} 2$ by $\mathrm{GABA}_{\mathrm{B}}$ Rs is crucial for fine tuning synaptic signaling, this mechanism likely contributes to plasticity and learning (Xu et al., 2007; Jung et al., 2016; Nanou et al., 2016).

Strikingly, we found that, as with GIRK, regulation of $\mathrm{Ca}_{\mathrm{V}} 2$ by RGS7 is facilitated by R7BP and inhibited by GPR158. Because both GIRK and $\mathrm{Ca}_{\mathrm{V}} 2$ are controlled by $\mathrm{GABA}_{\mathrm{B}} \mathrm{Rs}$ via the same mechanism, this outcome suggests that exclusion of RGS7 from regulation of $\mathrm{G} \beta \gamma$ signaling to ion channels may be a general mode of GPR 158 action. The exact mechanisms of this inhibitory influence of GPR158 are unclear at this point and will require further investigation, yet some speculations may be warranted.
Because GPR158 can modulate G-protein signaling initiated by traditional GPCRs (e.g., $\mu$-opioid receptor) when tested in a reconstituted system (Orlandi et al., 2012), it is possible that GPR158 may be involved in setting the selectivity of RGS7 actions toward certain GPCRs and/or effectors. Consistent with this idea, studies on the highly homologous orphan receptor GPR179, which likewise associates with RGS7, indicate that this protein complex imparts regulation of mGluR6 signaling to ion channel TRPM1 in retina ON-bipolar neurons (Ray et al., 2014). Remarkably, this regulation requires an assembly of an elaborate macromolecular complex that includes many components of the signaling cascade (Orlandi et al., 2013; Sarria et al., 2016). Identification of the receptors and effectors controlled by GPR158RGS7, as well as possible additional elements required for such control, will undoubtedly be an exciting research direction to pursue. Alternatively, it appears possible that GPR158 recruits RGS7 for its own intrinsic needs as a signaling GPCR. A recent study has suggested that GPR158 may signal via heterotrimeric G-proteins when activated with its proposed endogenous ligand osteocalcin (Khrimian et al., 2017). RGS proteins have been noted to associate with several canonical GPCRs, which is thought to modify their signaling properties (Abramow-Newerly et al., 2006; Anderson et al., 2009). In this context, RGS7 may thus act on G-proteins activated by GPR158 and thereby be excluded from regulation of G-proteins activated by other GPCRs such as $\mathrm{GABA}_{\mathrm{B}}$.

Overall, our findings support an emerging concept that R7 RGS proteins serve as an integral part of macromolecular signaling assemblies consisting of GPCRs, auxiliary subunits, and ion channels. We extend this model by illustrating that the composition of these complexes can be specifically tailored and that these changes in organization allow bidirectional functional tuning en- 
dowing GPCR cascades with the plasticity and high spatiotemporal precision needed for coordination of synaptic signaling.

\section{References}

Abramow-Newerly M, Roy AA, Nunn C, Chidiac P (2006) RGS proteins have a signalling complex: interactions between RGS proteins and GPCRs, effectors, and auxiliary proteins. Cell Signal 18:579-591. CrossRef Medline

Alonso I, Marques JM, Sousa N, Sequeiros J, Olsson IA, Silveira I (2008) Motor and cognitive deficits in the heterozygous leaner mouse, a Cav2.1 voltage-gated Ca2+ channel mutant. Neurobiol Aging 29:1733-1743. CrossRef Medline

Anderson GR, Semenov A, Song JH, Martemyanov KA (2007a) The membrane anchor R7BP controls the proteolytic stability of the striatal specific RGS protein, RGS9-2. J Biol Chem 282:4772-4781. CrossRef Medline

Anderson GR, Lujan R, Semenov A, Pravetoni M, Posokhova EN, Song JH, Uversky V, Chen CK, Wickman K, Martemyanov KA (2007b) Expression and localization of RGS9-2/G 5/R7BP complex in vivo is set by dynamic control of its constitutive degradation by cellular cysteine proteases. J Neurosci 27:14117-14127. CrossRef Medline

Anderson GR, Posokhova E, Martemyanov KA (2009) The R7 RGS protein family: multi-subunit regulators of neuronal $G$ protein signaling. Cell Biochem Biophys 54:33-46. CrossRef Medline

Cao Y, Pahlberg J, Sarria I, Kamasawa N, Sampath AP, Martemyanov KA (2012) Regulators of G protein signaling RGS7 and RGS11 determine the onset of the light response in ON bipolar neurons. Proc Natl Acad Sci U S A 109:7905-7910. CrossRef Medline

Chen CK, Eversole-Cire P, Zhang H, Mancino V, Chen YJ, He W, Wensel TG, Simon MI (2003) Instability of GGL domain-containing RGS proteins in mice lacking the G protein ${ }^{\star}$-subunit $\mathrm{G}^{\star} 5$. Proc Natl Acad Sci U S A 100:6604-6609. CrossRef Medline

Cramer NP, Best TK, Stoffel M, Siarey RJ, Galdzicki Z (2010) GABABGIRK2-mediated signaling in down syndrome. Adv Pharmacol 58:397426. CrossRef Medline

Dascal N, Kahanovitch U (2015) The roles of gbetagamma and galpha in gating and regulation of GIRK channels. Int Rev Neurobiol 123:27-85. CrossRef Medline

Davies CH, Starkey SJ, Pozza MF, Collingridge GL (1991) GABA autoreceptors regulate the induction of LTP. Nature 349:609-611. CrossRef Medline

Diversé-Pierluissi MA, Fischer T, Jordan JD, Schiff M, Ortiz DF, Farquhar MG, De Vries L (1999) Regulators of G protein signaling proteins as determinants of the rate of desensitization of presynaptic calcium channels. J Biol Chem 274:14490-14494. CrossRef Medline

Dolphin AC (2003) G protein modulation of voltage-gated calcium channels. Pharmacol Rev 55:607-627. CrossRef Medline

Doze VA, Cohen GA, Madison DV (1995) Calcium channel involvement in GABAB receptor-mediated inhibition of GABA release in area CA1 of the rat hippocampus. J Neurophysiol 74:43-53. CrossRef Medline

Drenan RM, Doupnik CA, Boyle MP, Muglia LJ, Huettner JE, Linder ME, Blumer KJ (2005) Palmitoylation regulates plasma membrane-nuclear shuttling of R7BP, a novel membrane anchor for the RGS7 family. J Cell Biol 169:623-633. CrossRef Medline

Drenan RM, Doupnik CA, Jayaraman M, Buchwalter AL, Kaltenbronn KM, Huettner JE, Linder ME, Blumer KJ (2006) R7BP augments the function of RGS7 ${ }^{\star}$ Gbeta5 complexes by a plasma membrane-targeting mechanism. J Biol Chem 281:28222-28231. CrossRef Medline

Fajardo-Serrano A, Wydeven N, Young D, Watanabe M, Shigemoto R, Martemyanov KA, Wickman K, Luján R (2013) Association of Rgs7/Gbeta5 complexes with girk channels and GABA receptors in hippocampal CA1 pyramidal neurons. Hippocampus 23:1231-1245. CrossRef Medline

Greif GJ, Sodickson DL, Bean BP, Neer EJ, Mende U (2000) Altered regulation of potassium and calcium channels by $\mathrm{GABA}(\mathrm{B})$ and adenosine receptors in hippocampal neurons from mice lacking Galpha(o). J Neurophysiol 83:1010-1018. CrossRef Medline

Han J, Mark MD, Li X, Xie M, Waka S, Rettig J, Herlitze S (2006) RGS2 determines short-term synaptic plasticity in hippocampal neurons by regulating Gi/o-mediated inhibition of presynaptic Ca2 + channels. Neuron 51:575-586. CrossRef Medline

Holz GG 4th, Rane SG, Dunlap K (1986) GTP-binding proteins mediate transmitter inhibition of voltage-dependent calcium channels. Nature 319:670-672. CrossRef Medline
Jayaraman M, Zhou H, Jia L, Cain MD, Blumer KJ (2009) R9AP and R7BP: traffic cops for the RGS7 family in phototransduction and neuronal GPCR signaling. Trends Pharmacol Sci 30:17-24. CrossRef Medline

Jung D, Hwang YJ, Ryu H, Kano M, Sakimura K, Cho J (2016) Conditional knockout of Cav2.1 disrupts the accuracy of spatial recognition of CA1 place cells and Spatial/Contextual recognition behavior. Front Behav Neurosci 10:214. CrossRef Medline

Khrimian L, Obri A, Ramos-Brossier M, Rousseaud A, Moriceau S, Nicot AS, Mera P, Kosmidis S, Karnavas T, Saudou F, Gao XB, Oury F, Kandel E, Karsenty G (2017) Gpr158 mediates osteocalcin's regulation of cognition. J Exp Med 214:2859-2873. CrossRef Medline

Klausberger T, Somogyi P (2008) Neuronal diversity and temporal dynamics: the unity of hippocampal circuit operations. Science 321:53-57. CrossRef Medline

Lujan R, Nusser Z, Roberts JD, Shigemoto R, Somogyi P (1996) Perisynaptic location of metabotropic glutamate receptors mGluR1 and mGluR5 on dendrites and dendritic spines in the rat hippocampus. Eur J Neurosci 8:1488-1500. CrossRef Medline

Lüscher C, Slesinger PA (2010) Emerging roles for G protein-gated inwardly rectifying potassium (GIRK) channels in health and disease. Nat Rev Neurosci 11:301-315. CrossRef Medline

Lüscher C, Jan LY, Stoffel M, Malenka RC, Nicoll RA (1997) G proteincoupled inwardly rectifying $\mathrm{K}+$ channels (GIRKs) mediate postsynaptic but not presynaptic transmitter actions in hippocampal neurons. Neuron 19:687-695. CrossRef Medline

Maity B, Stewart A, Yang J, Loo L, Sheff D, Shepherd AJ, Mohapatra DP, Fisher RA (2012) Regulator of G protein signaling 6 (RGS6) protein ensures coordination of motor movement by modulating GABAB receptor signaling. J Biol Chem 287:4972-4981. CrossRef Medline

Martemyanov KA, Yoo PJ, Skiba NP, Arshavsky VY (2005) R7BP, a novel neuronal protein interacting with RGS proteins of the R7 family. J Biol Chem 280:5133-5136. CrossRef Medline

Masuho I, Xie K, Martemyanov KA (2013) Macromolecular composition dictates receptor and $\mathrm{G}$ protein selectivity of regulator of $\mathrm{G}$ protein signaling (RGS) 7 and 9-2 protein complexes in living cells. J Biol Chem 288:25129-25142. CrossRef Medline

Montesinos MS, Chen Z, Young SM Jr (2011) pUNISHER: a high-level expression cassette for use with recombinant viral vectors for rapid and long term in vivo neuronal expression in the CNS. J Neurophysiol 106:3230 3244. CrossRef Medline

Nanou E, Scheuer T, Catterall WA (2016) Calcium sensor regulation of the CaV2.1 Ca2 + channel contributes to long-term potentiation and spatial learning. Proc Natl Acad Sci U S A 113:13209-13214. CrossRef Medline

Orlandi C, Posokhova E, Masuho I, Ray TA, Hasan N, Gregg RG, Martemyanov KA (2012) GPR158/179 regulate G protein signaling by controlling localization and activity of the RGS7 complexes. J Cell Biol 197:711-719. CrossRef Medline

Orlandi C, Cao Y, Martemyanov KA (2013) Orphan receptor GPR179 forms macromolecular complexes with components of metabotropic signaling cascade in retina ON-bipolar neurons. Invest Ophthalmol Vis Sci 54:7153-7161. CrossRef Medline

Orlandi C, Xie K, Masuho I, Fajardo-Serrano A, Lujan R, Martemyanov KA (2015) Orphan receptor GPR158 is an allosteric modulator of RGS7 catalytic activity with an essential role in dictating its expression and localization in the brain. J Biol Chem 290:13622-13639. CrossRef Medline

Ostrovskaya O, Xie K, Masuho I, Fajardo-Serrano A, Lujan R, Wickman K, Martemyanov KA (2014) RGS7/Gbeta5/R7BP complex regulates synaptic plasticity and memory by modulating hippocampal GABABR-GIRK signaling. eLife 3:e02053. CrossRef Medline

Padgett CL, Slesinger PA (2010) GABAB receptor coupling to G-proteins and ion channels. Adv Pharmacol 58:123-147. CrossRef Medline

Panicker LM, Zhang JH, Posokhova E, Gastinger MJ, Martemyanov KA, Simonds WF (2010) Nuclear localization of the G protein beta 5/R7regulator of $\mathrm{G}$ protein signaling protein complex is dependent on $\mathrm{R} 7$ binding protein. J Neurochem 113:1101-1112. CrossRef Medline

Pelkey KA, Chittajallu R, Craig MT, Tricoire L, Wester JC, McBain CJ (2017) Hippocampal GABAergic inhibitory interneurons. Physiol Rev 97:1619_ 1747. CrossRef Medline

Ray TA, Heath KM, Hasan N, Noel JM, Samuels IS, Martemyanov KA, Peachey NS, McCall MA, Gregg RG (2014) GPR179 is required for high sensitivity of the mGluR6 signaling cascade in depolarizing bipolar cells. J Neurosci 34:6334-6343. CrossRef Medline 
Sarria I, Orlandi C, McCall MA, Gregg RG, Martemyanov KA (2016) Intermolecular interaction between anchoring subunits specify subcellular targeting and function of RGS proteins in retina. J Neurosci 36:2915-2925. CrossRef Medline

Schiff ML, Siderovski DP, Jordan JD, Brothers G, Snow B, De Vries L, Ortiz DF, Diversé-Pierluissi M (2000) Tyrosine-kinase-dependent recruitment of RGS12 to the N-type calcium channel. Nature 408:723-727. CrossRef Medline

Schuler V, Lüscher C, Blanchet C, Klix N, Sansig G, Klebs K, Schmutz M, Heid J, Gentry C, Urban L, Fox A, Spooren W, Jaton AL, Vigouret J, Pozza M, Kelly PH, Mosbacher J, Froestl W, Käslin E, Korn R, et al. (2001) Epilepsy, hyperalgesia, impaired memory, and loss of pre- and postsynaptic GABA(B) responses in mice lacking $\operatorname{GABA}(\mathrm{B}(1))$. Neuron 31:47-58. CrossRef Medline

Song JH, Waataja JJ, Martemyanov KA (2006) Subcellular targeting of RGS9-2 is controlled by multiple molecular determinants on its membrane anchor, R7BP. J Biol Chem 281:15361-15369. CrossRef Medline

Stepan J, Dine J, Eder M (2015) Functional optical probing of the hippocampal trisynaptic circuit in vitro: network dynamics, filter properties, and polysynaptic induction of CA1 LTP. Front Neurosci 9:160. CrossRef Medline

Toro-Castillo C, Thapliyal A, Gonzalez-Ochoa H, Adams BA, Meza U (2007) Muscarinic modulation of Cav2.3 (R-type) calcium channels is antagonized by RGS3 and RGS3T. Am J Physiol Cell Physiol 292:C573-C580. CrossRef Medline
Victoria NC, Marron Fernandez de Velasco E, Ostrovskaya O, Metzger S, Xia Z, Kotecki L, Benneyworth MA, Zink AN, Martemyanov KA, Wickman K (2016) $\mathrm{G}$ protein-gated $\mathrm{K}(+)$ channel ablation in forebrain pyramidal neurons selectively impairs fear learning. Biol Psychiatry 80:796-806. CrossRef Medline

Wagner JJ, Alger BE (1995) GABAergic and developmental influences on homosynaptic LTD and depotentiation in rat hippocampus. J Neurosci 15:1577-1586. CrossRef Medline

Xie K, Allen KL, Kourrich S, Colón-Saez J, Thomas MJ, Wickman K, Martemyanov KA (2010) Gbeta5 recruits R7 RGS proteins to GIRK channels to regulate the timing of neuronal inhibitory signaling. Nat Neurosci 13:661-663. CrossRef Medline

Xu J, He L, Wu LG (2007) Role of Ca(2+) channels in short-term synaptic plasticity. Curr Opin Neurobiol 17:352-359. CrossRef Medline

Zamponi GW, Currie KP (2013) Regulation of $\mathrm{Ca}(\mathrm{V}) 2$ calcium channels by G protein coupled receptors. Biochim Biophys Acta 1828:1629-1643. CrossRef Medline

Zamponi GW, Lory P, Perez-Reyes E (2010) Role of voltage-gated calcium channels in epilepsy. Pflugers Arch 460:395-403. CrossRef Medline

Zhou H, Chisari M, Raehal KM, Kaltenbronn KM, Bohn LM, Mennerick SJ, Blumer KJ (2012) GIRK channel modulation by assembly with allosterically regulated RGS proteins. Proc Natl Acad Sci U S A 109:19977-19982. CrossRef Medline 